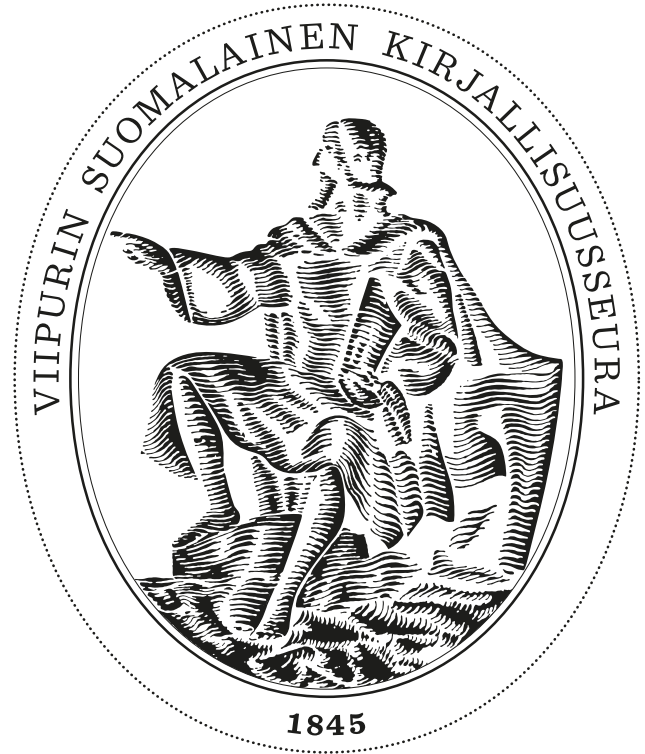

VIIPURIN SUOMALAISEN

KIRJALLISUUSSEURAN

TOIMITTEITA

(18)

Muuttuvien tulkintojen Viipuri 
Kansikuva: Osa Severin Falkmanin vuonna 1886 tekemästä öljymaalauksesta Kaarle Knuutinpoika Bonde lähdössä Viipurin linnasta Tukholmaan kuninkaanvaaliin 1448. Karl Knutson Bonde på väg från Viborgs slott till kungavalet i Stockholm 1448.

Kansallisgalleria/Kirsi Halkola. Ateneumin taidemuseo.

Viipurin Suomalaisen Kirjallisuusseuran Toimitteita osa 18 Muuttuvien tulkintojen Viipuri

Toimittaneet:

Anu Koskivirta (osan päätoimittaja),

Pentti Paavolainen (sarjan päätoimittaja),

Sanna Supponen (sarjan toimitussihteeri)

Kuvatoimitus:

Risto Marjomaa

Graafinen suunnittelu \& taitto:

Eemeli Nieminen, www.eemelinieminen.fi

ISBN: 978-952-67216-3-7 (Toimite 18, PDF)

ISSN: 1236-4304 (Sarja)

Painettu: 2016, Juvenes Print

Painosmäärä: 200 kpl

2. korjattu painos.

Julkaisija: Viipurin Suomalainen Kirjallisuusseura, Helsinki 


\section{Valistuskirjoista muistelmiin: Viipurin kirjallisia sukupolvia}

Suomenkielistä kirjallisuutta alettiin julkaista Viipurissa 1810-luvulta lähtien, mikä on maassamme varhainen ajankohta. Jo 1830-luvulla virisi myös suomenkielisen sanomalehdistön toiminta. Viipurin asemaa kirjojen kaupunkina vahvisti niin ikään Viipurin Suomalaisen Kirjallisuusseuran (jatkossa VSKS) perustaminen vuonna 1845 ja seuran toiminta esimerkiksi valistus- ja oppikirjojen julkaisijana.

Vielä 1960-luvun historiantutkimuksessa Viipurin suomenkielisen julkaisutoiminnan vahva asema tulkittiin suomenmieliseksi reaktioksi Vanhan Suomen (Viipurin läänin) sosiaalisen rakenteen jälkeenjääneisyyteen ja lahjoitusmaatalonpoikien vaikeaan asemaan. ${ }^{1}$ 200o-luvun historiantutkijat taas ovat halunneet nähdä sen pikemminkin osoitukseksi vilkkaasta säätykierrosta, jonka ansiosta suomenkielisen maaseuturahvaan poikia onnistui nousemaan kaupungin kauppiaskuntaan jo ennen 1800-luvun puoliväliä. Näin he saivat mahdollisuuden edistää äidinkielensä asemaa yhteistyössä kaupunkiin asettuneen, runebergiläisen herätyksen kokeneen opettajapolven kanssa. ${ }^{2}$

Tämä artikkeli tarkastelee Viipurin suomenkielisen kirjallisuuden kahta aloittajaa, Jaakko Juteinia ja Pietari Hannikaista, sekä heitä seuranneita viipurilaiskirjailijoiden ja sanomalehtimiesten sukupolvia aina toisen maailmansodan jälkeiseen diasporakauteen saakka. Viipurilaisuus on nähty artikkelissa laveasti: tarkastelun kohteina ovat sekä Viipurissa syntyneet että kaupungissa jossain elämänsä vaiheessa toimineet kirjailijat ja lehtimiehet. Ikäpolvien lomassa tarkastellaan kirjailijan työn taloudellisesti mahdollistaneiden instituutioiden kehitystä ja suurimpien kieliryhmien välistä dynamiikkaa.

\section{KOLME KULTTUURITOIMINNAN VAIHETTA 1800-LUVULLA}

Charlotta Wolff periodisoi edellä kulttuurin tuottamisen ja kuluttamisen muodot 180o-luvun Viipurissa kolmeen vaiheeseen. Monien maiden kulttuurihistoriaa kuvaava jäsennys sopii myös Viipurin suomenkielisten kirjoittajien, lukijoiden ja kulttuurin välittäjien tarkastelemiseen, kun muistetaan, että siirtymät eivät koskaan olleet tarkkarajaisia eivätkä yhtäaikaisia. ${ }^{3}$ 
Aristokratian ja kauppaporvariston elämäntapaan kuului taiteiden harrastaminen. Harrastajien eli asiaa rakastavien (Liebhaber, amateur, dilettante) kulttuuri kattoi musiikin, kuvataiteet ja säätyläisnuorison seuranäytännöt (sällskapsspektakel). Päiväkirjan pitäminen ja runojen kirjoittaminen kuuluivat säätyläisten itseilmaisun muotoihin, lukeminen taas tärkeimpiin ajanvietteisiin. Viipuriin syntyi vuonna 1806 ensimmäinen säätyläisille tarkoitettu lukuyhdistys, jolla oli saksankielinen kirjasto. Laajempi lukuyhdistys kirjastoineen sekä Juho Pynnisen kansankirjasto perustettiin 1840-luvulla. ${ }^{4}$

Toisena vaiheena $1800-l u v u n$ kuluessa vaurastuneen porvariston piirissä syntyi valmius taiteiden mesenointiin: taidetta tekivät jo sen ammatikseen ottaneet saaden maksun työstään. Myös sanomalehtien tilaaminen ja julkaisujen ennakkotilausjärjestelmä voidaan nähdä osaksi kirjallisen elämän mesenointia.

Kirjallisuutta ei yleensä tuettu suorin avustuksin tai tilaamalla teoksia. Julius Krohnin isä, Leopold Wilhelm Krohn tosin maksoi poikansa yllyttämänä Aleksis Stenvallille 100 ruplan stipendin vuosina 1860 ja $1861 .{ }^{5}$ Stenvall joutui silti tuottamaan omakustanteita ja tavoittelemaan kirjallisia palkintoja tullakseen toimeen. Ainakin kerran hän kääntyi myös Viipurin Suomalaisen Kirjallisuusseuran puoleen. ${ }^{6}$ Viipurissa saksan- ja ruotsinkieliset kauppiaspiirit tarjosivat mallin, kun vaurastuneet suomenkieliset alkoivat toimia mesenaatteina. Tunnetuin esimerkki tällaisesta taiteen kannattamisesta on kauppaneuvos Juho Lallukan ja hänen piirinsä panos monien kulttuurihankkeiden rahoittajina. Kirjallisuutta Lallukka edisti maksamalla pysyvää apurahaa runoilija J. H. Erkolle sen jälkeen, kun tämä oli lopettanut opettajantyönsä Viipurissa. ${ }^{7}$

Kolmannessa vaiheessa syntyivät instituutiot, joita pohjusti kulttuurin kuvataiteen, musiikin ja teatterin - ammattiryhmien organisoituminen taiteilijaseuroiksi ja muiksi yhdistyksiksi. Kaupungin kirjastotoimi puolestaan eteni 1860-luvulla vielä yksityisten lahjoittajien eli lähinnä Hackmanien varassa, kunnes kaupunki alkoi osallistua sen kuluihin vuodesta 1874 lähtien. ${ }^{8}$

Lehdistön osalta mesenaattien ja instituutioiden rooleja jäsentävät erityisesti aatteelliset organisaatiot, poliittinen ilmasto ja talouden suhdeverkostot. ${ }^{9}$ Kirjallisuuskritiikki kehittyi rinnan sanomalehdistön kanssa, kun kirjapainot puolestaan toimivat käytännön pakosta kustantajina. Kirjapainoalan, kirjankustantamisen ja kirjamyynnin privilegio säilyi Viipurissa Cederwallerin perhekunnan hallussa, kunnes yhtiöön tuli 1850-luvulla lisää osakkaita, esimerkiksi liberaali lehtimies ja kirjailija Johannes Alfthan. ${ }^{10}$ 1860-luvun alussa Viipurin johtavaksi kirjapainoksi nousi maisteri N. A. Zilliacuksen yhtiö, joka kustansi myös sanomalehtiä." 


\section{SUOMENKIELISEN VÄESTÖN VIRTA VIIPURIIN}

Viipurin väkiluvun kehitys ja muuttuvat kielisuhteet havainnollistuvat kaaviossa, joka perustuu Yrjö Kaukiaisen laskelmiin. ${ }^{12}$ Kaavio 1 osoittaa, että suomenkieliset olivat suurin väestöryhmä (44 prosenttia) jo tarkastelujakson alussa (1812), kunnes ruotsinkielistä väestöä alkoi muuttaa kaupunkiin 1840-luvulla. Suomenkielisen väestön osuuden kasvu kiihtyi erityisesti Saimaan kanavan (1856) ja Pietarin radan (1870) valmistumisen jälkeen.

Viipuriin muuttaessaan suomenkieliset kuuluivat pääosin alempiin yhteiskuntakerroksiin. Vuonna 1870 noin 70 prosenttia kaupungin työväestöstä oli suomenkielisiä ja 10 prosenttia ruotsinkielisiä lopun viidenneksen ollessa venäläisiä. Sen sijaan vain vajaa kahdeksan prosenttia kaupungin suurliikemiehistä, virkamiehistä, opettajista, papistosta ja muusta säätyläistöstä ilmoitti itsensä suomenkielisiksi. Osa heistä oli säätynousijoita, osa taas kielikäännynnäisiä, jotka olivat sitoutuneet suomen kielen aseman edistämiseen..$^{13}$

Viipurin kieliolosuhteet muuttuivat nopeammin kuin Helsingissä tai Turussa, joissa suomen etenemistä enemmistökieleksi hidasti ruotsinkielisen rahvaan suuri osuus. Vuonna 1870 viipurilaisten enemmistön (54 \%) kielenä oli suomi, kun Helsingin asukkaista vielä 57 prosenttia oli ruotsinkielisiä. Myös Turussa suomenkielisiä oli jo niukka enemmistö, kun Helsingin kielisuhteet tasaantuivat vasta 20 vuotta myöhemmin. Vuonna 1890 yli kaksi kolmasosaa Viipurin asukkaista oli suomenkielisiä, kun ruotsinkielisiä oli enää alle 15 prosenttia. ${ }^{14}$ Paikalliset kieliolot selittävätkin Viipurissa syntyneiden suomenkielisten kulttuuri-instituutioiden elinvoimaisuutta.

Kieliolojen nopeaa muutosta selitti Viipurin nousu Itä-Suomen kaupan ja teollisuuden keskukseksi, koska sen aiheuttama huomattava väestönlisäys koostui lähes yksinomaan suomenkielisistä. Kun elinkeinovapaus vauhditti samaan aikaan sosiaalista kiertoa, suomenkielisistä kauppiaista, virkamiehistä ja heidän palveluskunnastaan muodostui laaja suomenkielisen kulttuurin kuluttajien ryhmä. Myös työväestä tuli sen omien rientojen syntyessä kulttuuria kuluttava ja sitä omaehtoisesti tuottava ryhmä etenkin vuosisadan vaihteen jälkeen. Suuri osa työläisistä tosin asui pitkään virallisesti maalaiskunnan puolella, sillä tulokkaat asettuivat pääasiassa kaupungin neljän sisääntuloväylän varteen. Niihin muodostuneet esikaupunkialueet liitettiin Viipurin kaupunkiin vuosina 1923-1933.

\section{VÄINÄMÖISEN SUOJELUKSESSA: JAAKKO JUTEINI}

Viipurin suomenkielistä julkaisutoimintaa kannatteli pitkään maistraatin sihteeriksi vuonna 1813 nimitetyn Jacob Judénin (1781-1855) kirjailijantyö. Suomenkielisen tuotantonsa Hattulassa syntynyt, Hämeenlinnassa piirikoulun käynyt 


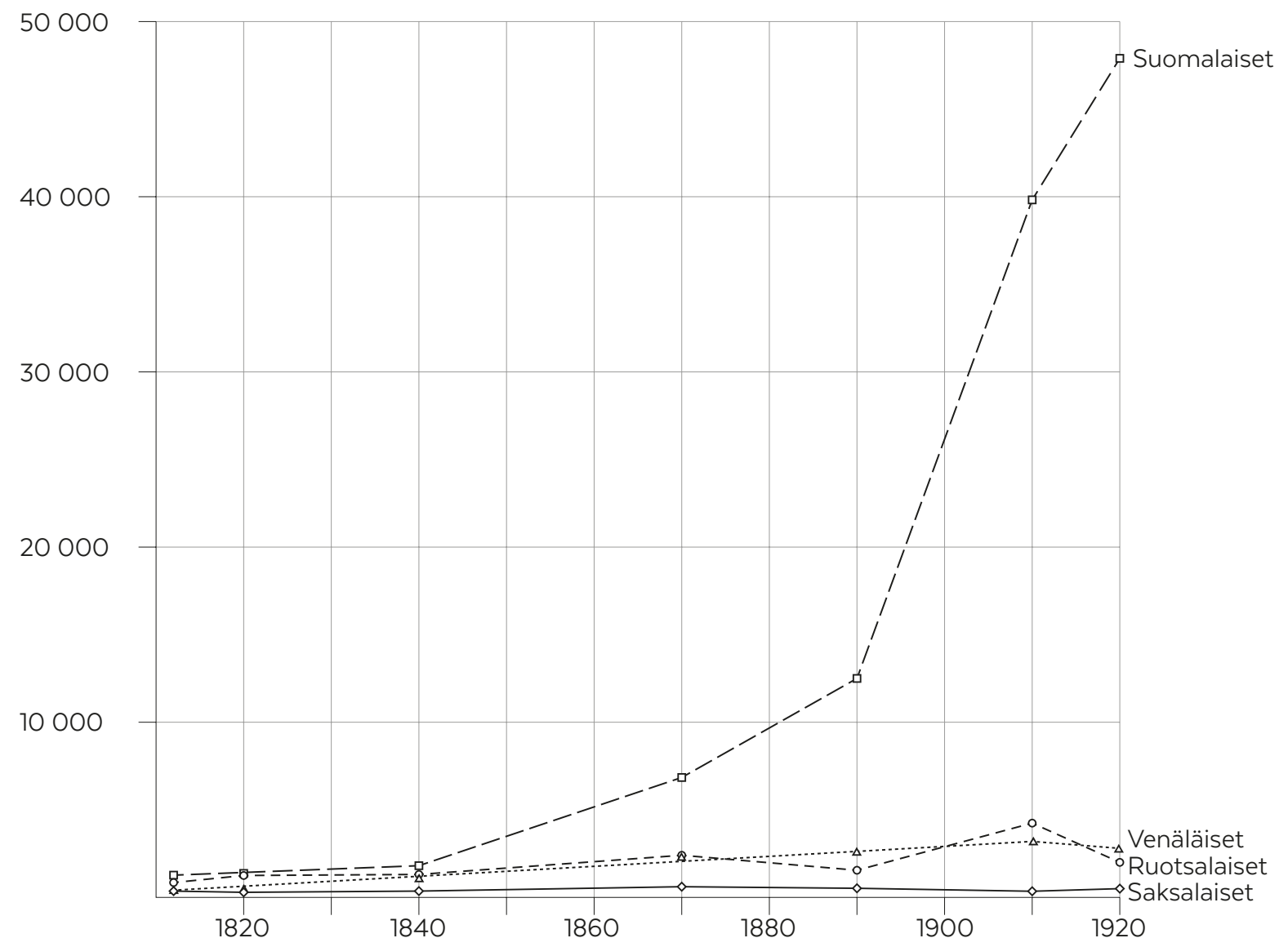

Kaavio 1 Viipurin väestön kieliryhmät 1812-1920. Lähde: Kaukiainen 2013, 76.

ja Henrik Gabriel Porthanin piirissä opiskellut Judén julkaisi vuosina 1810-1844 Jak. Juteinin nimellä. Juteini on ollut tapana nimetä ensimmäiseksi laajan ja kunnianhimoisen suomenkielisen tuotannon kirjoittaneeksi kirjailijaksi. Hän täyttää myöhemmät käsitykset ammattimaisesta kirjailijasta. Samalla hän edustaa toista pitkää perinnettä: sivutoimista kirjailijaa, joka virkamiehen päivätyön ohella omistautui harrastajan (Liebhaber) antaumuksella taiteelliseen työhön. Sivutoimi oli virkamiehelle vapauden valtakunta, jossa Juteininkin esimiehenä oli vain "runon isä Wäinämöinen."

Jo Judénin nimittämistä edeltäneiden vuosien Viipurissa oli virinnyt harrastuneisuutta Suomen maantieteeseen ja suomalaiseen kulttuuriin. Niiden pariin kaupungin uuteen lukioon (per. 1805) palkatut saksalaiset opettajat kannustivat oppilaitaan. Erityisesti runoudesta tuli tärkeä keino istuttaa nuorisoon isänmaanrakkautta. Tunnetuin Suomea käsittelevistä teoksista oli koulutarkastaja August Thiemen (1780-1860) runoelma Finnland (1808), jossa 


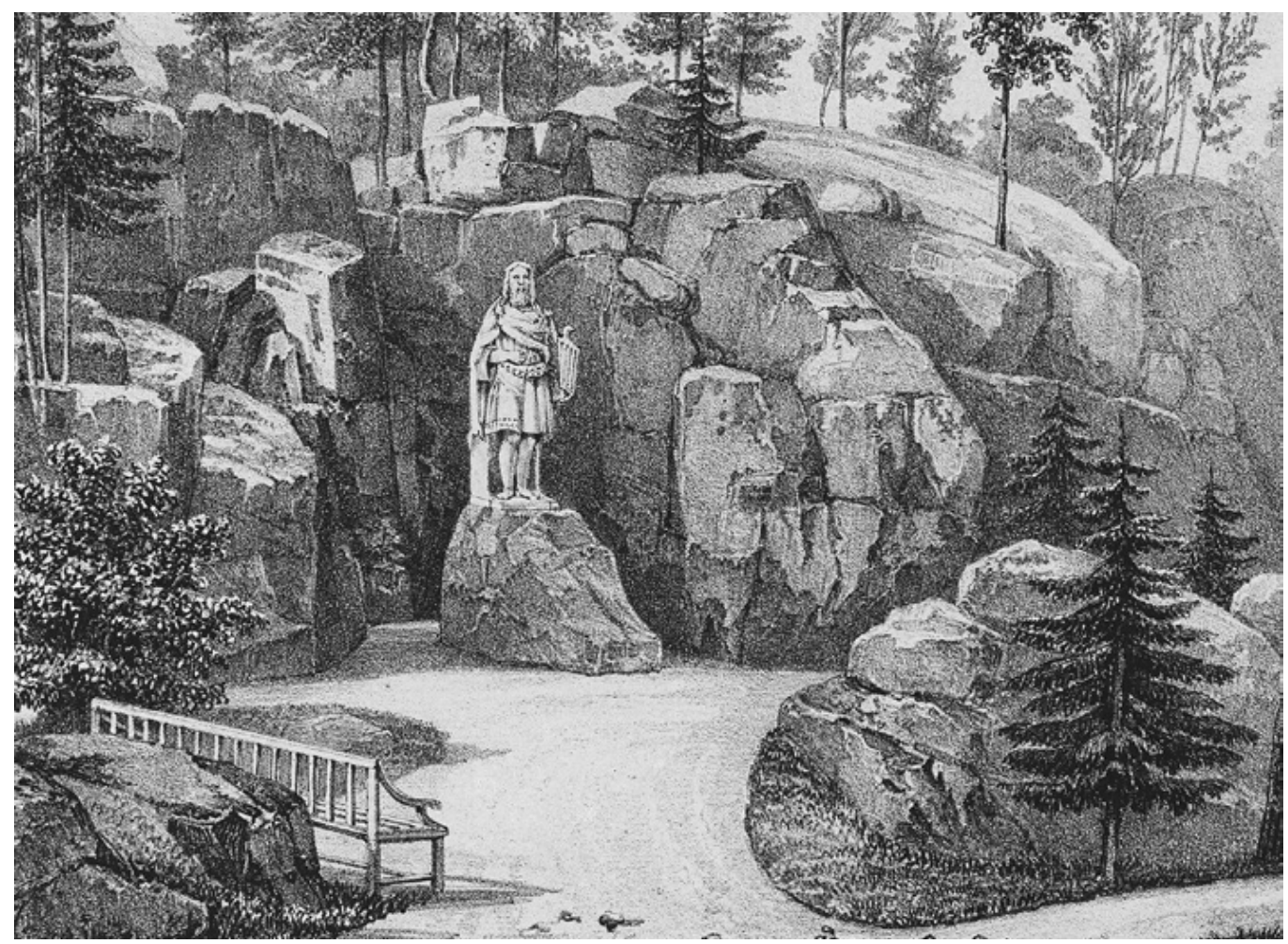

Väinämöisen patsas Monrepos'n puistossa Paul Nicolayn vuonna 1840 julkaisemassa kuvitetussa uusintapainoksessa isänsä Ludwig Heinrich von Nicolayn kirjasta Das Landgut Monrepos (1804). Kuvituksesta vastasi ranskalainen Jean Louis Jacottet (1806-1880), jonka litografiat pohjautuivat tanskalaisen Christian Ferdinand Christensenin (1805-1883) akvarelleihin. Patsaan teki tanskalainen kuvanveistäjä Gotthelf Borup (1804-1879).

hän heksametri- ja elegiamittaa vuorottaen peilaa Pohjolan villiin luontoon liittyviä ennakkokäsityksiä välittömiin maisemakokemuksiin. Muutamaa vuosikymmentä aiemmin muotoillun germaanis-skyyttalaisen mytologian piiriin tuli näin vedetyksi myös kaukainen fennien maankolkka, jolla nähtiin sivistys ja kukoistus edessään. ${ }^{15}$ Niin ikään Thieme kokosi ja painatti suomalaisia sananlaskuja saksannoksineen. Lukion suomalaisuusharrastukset väistyivät koulumiesten muuttaessa pois 1810-luvun alkuvuosina.

Ei ole tiedossa, oliko Jacob Judén kuullut Viipurin lukion piirin tuolloin jo hiipuneista suomalaisuusharrastuksista. Viipurissa Judén julkaisi ystävänsä kirjanpainaja Anders Cederwallerin kustantamana parikymmentä erilaajuista kirjaa, samoin yksittäisiä suomenkielisiä runoja saksankielisen sanomalehden Wiburgs Wochenblattin (1823-1832) liitteissä. ${ }^{16}$ Nimimerkillään Juteini avusti säännöllisesti myös Abraham Poppiuksen ja K. H. J. Ignatiuksen toimittamaa Sanan Saattajaa Viipurista (1833-1836, 1840-1841). 
Juteinin tuotantoon kuuluu runoutta ja proosaa, pari näytelmää, sananlaskuja, arvoituksia sekä esimerkiksi kirjoituksia lasten ja nuorison kasvatuksesta. Yhteiskunnallisesti tarkkasilmäinen Juteini muun ohella kirjoitti novellin "horjahtaneesta" tytöstä, joka oli surmannut salavuoteuden seurauksena syntyneen lapsensa. Uskonto ja valistushenkisyys taas yhdistyivät esimerkiksi hänen Jeesusta käsittelevässä runossaan Sangari Siionissa (1826). Niin ikään Juteini kirjoitti mietelmäkirjallisuutta, moitti taikauskoisuutta, tuomitsi väkivallan ja kiinnitti huomiota eläinten hyvinvointiin ja oikeuksiin. Näiltä osin hänen ajatuksensa ovat osin niin moderneja, että niillä on kaikupohjaa edelleen. Judénin nimellä hän julkaisi ruotsiksi kirjoituksia suomen kielestä, uskonnosta ja filosofiasta.

Juteinin runotuotantoon kuuluu lyyrisiä paloja laajempiakin panoraamoja. Niitä ovat esimerkiksi runoelmat, joissa hän joko ylistää Aleksanteri I:tä rauhan tuojana tai venäläisiä, jotka karkottivat tunkeilija Napoleonin. Sittemmin nämä kuvaukset venäläisten urhoollisuudesta jäivät Suomessa poliittisista syistä unohduksiin.

Juteini kirjoitti toistuvasti Väinämöisestä, joka oli hänelle henkilökohtaisesti tärkeä. Hän näet koki itsensä yhdeksi "suomalaisista runolaisista", joiden suojelushenki tai jumaluus Väinämöinen oli. Hän katsoi suomalaisten runolaisten työskentelevän Väinämöisen innoittamana, mutta - kirjallista konventiota noudattaen - Väinämöisen vertaiseksi koskaan pääsemättä. Tämän kaavan mukaisesti Juteini surkutteli asiaankuuluvasti omien kyhäelmiensä mitättömyyttä ja pyysi niitä anteeksi Väinämöisen edessä.

Juteini nojautui Väinämöis-kuvastossaan vielä Christfrid Gananderin ja H. G. Porthanin esittämiin tietoihin. ${ }^{17}$ Siksi Väinämöinen oli hänelle valistuksen hengessä "viisas vanha Väinämöinen, runon isä riemullinen". Vasta Lönnrotin Kalevalan versioissa $(1835,1849)$ toistuvaksi epiteetiksi vakiintui auktoriteettia korostava "vaka vanha Väinämöinen".

Juteinin tekstit vahvistivat silti osaltaan Väinämöis-kulttia. Kuuluisan runotervehdyksensä "Väinämöinen, voimallinen, runon isä riemullinen" hän kirjoitti vuonna 1831, kun Monrepos'n kartanon puistoon hankittiin tanskalaisen G. Borupin veistämä Väinämöisen patsas. ${ }^{18}$

Juteinin Perhekunda ja Pila pahoista hengistä ovat varhaisimmat suomeksi painetut näytelmät. Ne on kirjoitettu vuonna 1817, pian sen jälkeen, kun C. G. Bonuvierin ruotsinkielinen teatteriseurue Turusta oli ensi kertaa vieraillut Viipurissa (1816). Perhe-kunda, Pila-Kirjoitus Epä-Luulosta Kolmessa Osassa (1817) tähdentää kouluopetuksen ja luonnontieteellisen maailmankuvan hyödyllisyyttä verrattuna liialliseen jumalisuuteen ja taikauskoisuuteen. Kylän tietäjäkin saattoi menestyä vain, koska tyhmät maksoivat hänelle loitsuista. ${ }^{19}$ Perhekun- 


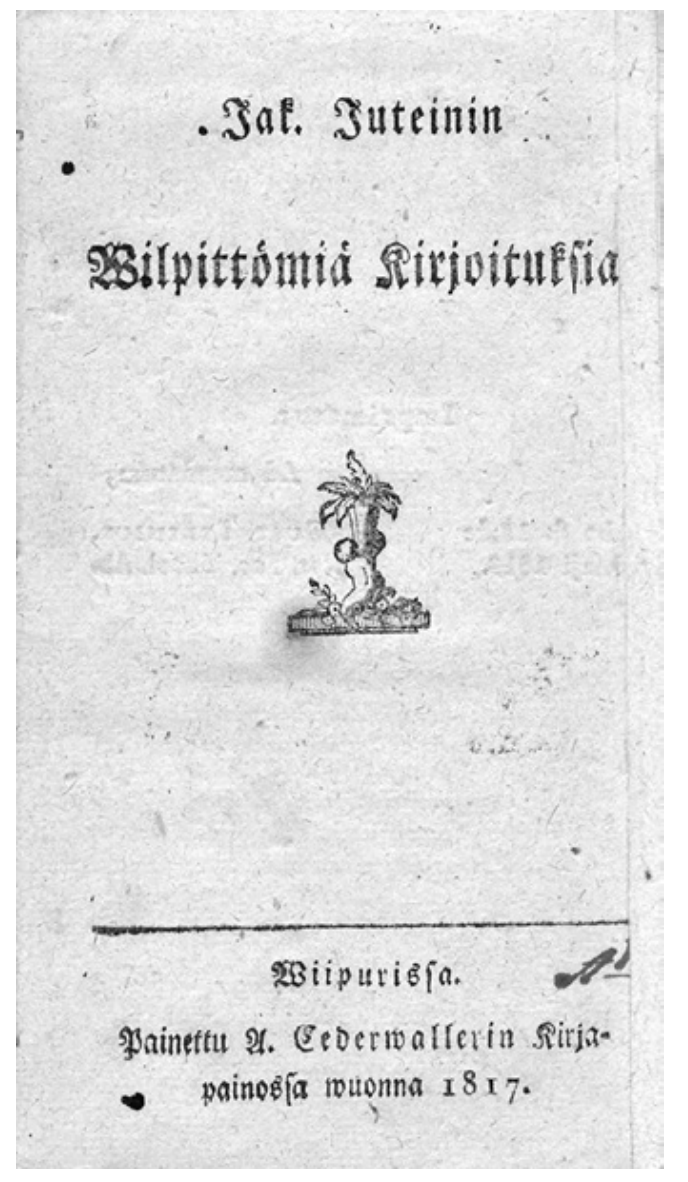

Kansilehti Jaakko Juteinin teoksesta Wilpittömiä kirjoituksia, joka painettiin Anders Cederwallerin kirjapainossa Viipurissa vuonna 1817. nan jälkinäytökseksi Juteini kirjoitti Pilan pahoista hengistä, Kolmessa Kanssa-puheessa Uskon Wahwistukseksi (1817). Siinä helvetin pikkupirut joutuvat virattomiksi, kun maan päällä leviää valistus. Tyhmyyttään pirut ryömivät pyssyn piippuun, josta heidät pamautetaan ilmaan. Käytännössä Juteini kirjoitti näin kokonaisen teatteri-illan suomenkielisen ohjelman: valistusnäytelmän ja sen jatkoksi yksinäytöksisen fantasian tai "taikapilan".

Juteinin tuotteliain kausi kesti kolmen vuoden ajan: vuosina 1816-1818 hän julkaisi yli puolet siitä, mikä kattaa hänen Koottujen teostensa uusimman laitoksen. Tuolloin ilmestyneet satiiriset runot sekä papistoa koskevat moitteet tuohduttivat erityisesti Virolahden kappalaista Fr. Joh. Ahlqvistiä, joka aloitti hyökkäyksensä kirjailijaa vastaan. Kappalainen Ahlqvist ei ollut itsekään huono runoilija. Hän vastasi soimauksiin reippaasti kirjoittamalla häväistysrunon, jossa Juteinia syytettiin omanvoitonpyynnistä, kaksinaismoraalista ja tekopyhyydestä. Runossa torjuttiin Juteinin moitteita papistoa kohtaan ja kiellettiin kylvämästä talonpoikien pariin kaikenlaisia pahoja luuloja papeista. ${ }^{20}$ Kirjallinen kiista jatkui vastineiden vastineina, ja sen seurauksena Juteini yritti pitää taukoa kirjailijantoimestaan, muttei lopulta voinut. ${ }^{21}$ Kirjailijan henkistä prosessia kuvaavat teosten otsikot: Lähtö-Laulu, eli hyvästijättö Väinämöiselle (1819) ja seuraavana vuonna julkaistu Huilun humina eli takaisintulo Väinämöisen hyvästijätöstä. Juteini palasi tauoltaan entistä pehmeämpänä. Kritiikki oli muuttunut aiempaa verhotummaksi ja olojen suoran arvostelun korvasivat nyt rakentavat ehdotukset esimerkiksi maanomistusolojen järjestämiseksi.

Hyökkäykset kirjailijaa vastaan eivät silti päättyneet. Jacob Judén onkin Suomen ainoa kirjailija, jonka teoksen painos on poltettu julkisesti. Kyseessä oli kokoelma Anteckningar uti varianta ämnen (1827), josta oli kanneltu nimettömäs- 
ti viranomaisille. Kirjan perusteella Judén sai syytteen uskontunnustuksen ja evankelisen opin vastaisten mielipiteiden esittämisestä. Koska tutkinnassa kävi ilmi, ettei kokoelmalle ollut haettu uskonnollisille teoksille tarvittavaa Porvoon tuomiokapitulin painatuslupaa, maaherra määrättiin takavarikoimaan kirjan vielä kokonaan myymätön painos. Viipurin kämnerinoikeus tuomitsi Judénin ja kustantaja Cederwallerin sakkorangaistukseen. Painos puolestaan määrättiin hävitettäväksi. Tuomio pantiin toimeen Viipurin torilla tammikuussa 1829. Tosin myöhemmin ylemmät oikeusasteet kumosivat rangaistukset. Lainvoimaisen tuomion perusteet ja Juteinin suhtautumisen oikeudenkäyntiin Liisi Huhtala tiivistää seuraavasti:

Tämän [Judénin] 'lausunnot uskonnosta ja kristinopista olivat niin pimeästi ja epäselvästi esitetty', ettei voinut päättää, mitä hän oikein tarkoitti, varsinkaan kun hän itse vakuutti, ettei ollut aikonut esittää kirkonvastaisia mielipiteitä. Seuraavan teoksensa, joka ilmestyi vasta vuonna 1844, esipuheessa Juteini kertoo polttaneensa oikeusprosessin aikana aiemmat kirjoituksensa, 'murtunein mielin'.22

Sittemmin tuomiot ja häväistyskirjoitukset vaihtuivat kunnianosoituksiksi. Jäädessään eläkkeelle maistraatin virasta vuonna 1840 Judénille myönnettiin ruotsinkielisten tutkielmiensa ansiosta Helsingin yliopiston kunniatohtorin arvo. Syksyllä 1845 taas Judén sai itseoikeutetusti kirjoittaa ensimmäisenä nimensä Viipurin Suomalaisen Kirjallisuuden Seuran (VSKS) perustamisasiakirjan. Tarjotusta seuran esimiehen tehtävästä hän sen sijaan kieltäytyi korkeaan ikäänsä vedoten. ${ }^{23}$

Judén valmisteli viimeisinä vuosina koottuja teoksiaan, jotka ilmestyivät hänen poikansa toimittamina Jak. Juteinin Kirjoina postuumisti vuosina 18561858. Kirjailijan viimeisessä Väinämöis-runossa, "Väinämöisen itkussa" toistui vielä kerran ajatus Väinämöisestä iloisena isänä, elämänuskoa valavana kulttuuriheeroksena. Runossa kirjailija nimittäin liitti näynomaisesti yhteen Väinämöisen ilon kyynelet ja niistä syntyvät purot, järvet, joet ja meret. ${ }^{24}$ Jacob Judén ehti kuolla vuonna 1854 vain hiukan ennen kuin Saimaan kanava avattiin liikenteelle. Hän oli senkin kunniaksi jo ehtinyt runoilla.

Vaikka Juteinin kirjoja myytiin ja levitettiin kaikkialla Suomessa, hän jäi taka-alalle Helsingin säätyläistön vakiinnuttamassa kansallisten suurmiesten kaanonissa. Myöhemmin hänen arvonsa tunnustettiin, mutta mitään Runebergiin tai Kiveen verrattavaa kulttia Juteinin ympärille ei muodostunut. Nähtävästi teosten kieli koettiin vanhanaikaiseksi ja maailmankuvakin naiiviksi ja tarkoitushakuiseksi. Tuotantoa ei myöskään ollut helposti saatavilla. ${ }^{25}$ 


\section{RADIKALISOITUVA FENNOMANIA - KANAVA JA PIETARI HANNIKAINEN}

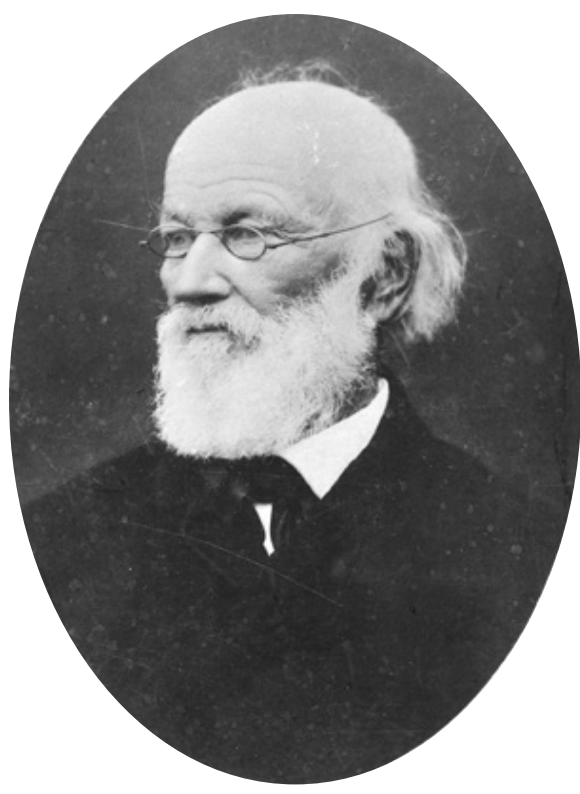

Kirjailija ja lehtimies Pietari Hannikainen vanhoilla päivillään.

Viipurin säätyläispiireissä fennomanian päämäärät olivat sosiaalisempia kuin 1830-luvun runebergiläisessä romantiikassa, jossa suomalaista kansaa ihannoitiin kaukaa. Fennomaanipiirien organisoitumista ja muotoja inspiroi Snellmanin 1840-luvulla Kuopiosta käsin julistama yhteiskunta- ja elinkeinopoliittinen kansallinen herätys.

Viipurin Suomalaisen Kirjallisuusseuran perustajat (1845) ja muut suomalaisuusliikkeen käynnistelijät Judénin lisäksi olivat pääasiassa lukion opettajia ja kauppakonttoristeja, jotka lukeutuivat jo uuteen sukupolveen. Heidän yhdistystoimintansa ja kirjallinen aktiviteettinsa oli vielä erillään leipätyöstä, joskin nivoutui orgaanisesti seuran keskeisten luottamushenkilöiden kansanopetustoimintaan. ${ }^{26}$

Osa opettajista oli maalaispappeina, laitossaarnaajina tai nimismiehen poikina nähnyt, millaisia ongelmia vieras virkakieli aiheutti suomenkielisen rahvaan parissa - niin tuomioistuimissa kuin hallinnollisiakin asioita hoidettaessa. ${ }^{27}$ Tämä valistunut etujoukko määritti kirjallisuusseuran tehtäväksi koota ja julkaista hyödyllisiä suomenkielisiä kirjoja sekä edistää niiden leviämistä ja yleistä suomen kielen "hoitoa", samoin kerätä "muinaiskaluja”. Seuran säännöt oli pitkälti kopioitu Helsingin akateemisten piirien perustamalta Suomalaisen Kirjallisuuden Seuralta (1831), jolle oli keväällä 1845 ehdotettu perustettavaksi alaosastoja maakuntiin. Viipurin SKS perustettiin kuitenkin itsenäiseksi seuraksi. ${ }^{28}$

VSKS:n melko maltillisten voimien sijaan Viipurin suomalaisuustoiminnalle loivat radikaalin jälkimaineen useat paikalliset lehtimiehet, heistä ensimmäisenä Pietari Hannikainen (s. Peter Hanén 1813-1899). Hänen kirjoitustensa vaikutus ulottui Juteinia laajemmalle siksi, että hän toimi pitkän elämänsä aikana lehtimiehenä useissa vaikutusvaltaisissa sanomalehdissä. Lehdistöhistoriassa hänet onkin nähty uudenaikaisen sanomalehdistön tienraivaajaksi. ${ }^{29}$

Yhteistä Juteinille ja Hannikaiselle oli julkisista varoista rahoitettu siviilivirka, kaunokirjallinen tuotanto sekä halukkuus ja valmius julkiseen keskusteluun lehdistössä. Molemmilla on paikka kansallisen kirjallisuuden kaanonissa, joskin vain Aleksis Kiven edeltäjinä. Hiukan samaan tapaan Viipurin valistuksellinen ja sosiaalinen fennomania (1840-1865) on jäänyt yleisesityksissä idealistisen Lauantaiseuran sekä Snellmanin ja Yrjö Koskisen edustamien sosiaalisen

106 | SUOMENKIELISEN KIRJALLISUUDEN KAUPUNKI 
fennomanian suuntausten varjoon. ${ }^{30}$

Peter Hanén (Hannikainen) oli sääminkiläisen lautamiehen poika ja käynyt Savonlinnan saksankielistä piirikoulua. Kenties kouluaikainen tutustuminen saksankielisen kirjallisuuden alkeisiin avasi hänelle ikkunaa saksalaisen kulttuuripiirin aikalaiskeskusteluun. Hanénin aloittaessa 20-vuotiaana yliopisto-opinnot Helsingissä kansalliset harrastukset olivat virinneet ja SKS perustettu. Hän suoritti yliopistossa vapaaehtoisen suomen kielen kokeen ja maanmittarin tutkinnon palaten vuonna 1835 Itä-Suomeen maanmittarin apulaiseksi. Tulevaa elämänuraa ajatellen virka oli oiva näköalapaikka eri kansanluokkien elämään, seudullisiin maanomistusoloihin sekä muunlaisiin ajankohtaisiin kieli- ja riitakysymyksiin. Vuonna 1844 Hannikainen julkaisi Snellmanin Saimassa ensimmäisiä suomenkielisiä runojaan ja ryhtyi omaan sanomalehtihankkeeseen Viipurissa. ${ }^{31}$

Marraskuussa 1844 kirjanpainaja Anders Cederwallerin leski ja poika jättivät anomuksen Sanan Saattaja-lehden julkaisemisen jatkamiseksi. Sen privilegio oli entuudestaan heidän hallussaan. Nimeksi haluttiin Kanawa. Sanan-Saattaja Wiipurista. Yhtenä perusteena oli suuri Saimaan kanavan rakennushanke, jota koskevia uutisia lehdessä julkaistaisiin. Luvat järjestyivät nopeasti, sillä Kanavan ensimmäinen numero ilmestyi jo $4.1 .1845{ }^{32}$

Hannikaisen lukijoille osoittama ohjelmateksti oli muotoiltu yleisen valistavaksi, mutta käytännössä se edusti jo modernin julkisuuden periaatteita. Julkinen sana nähtiin siinä yleisten asioiden keskustelufoorumiksi, jollaista yhteiskunta (yhteisyys) kaipaa tai tarvitsee.

\section{Kunnioitettawalle yhteisyydelle Suomessa.}

Valistus ja siwistyminen owat kansallisuuden rauhalliset harjoitukset. Kirjallisuus on pelto jossa ne kaswawat, lisäntywät ja uudistuwat, Me voimme siis ja sanoa, että walistus ja siwistyminen waatiivat myös Kirjallisuutta eli julkisuutta. Samatekun yksinäinen ihminen ei ole tytywäinen ennen kuin hään saa ilmoitta mielalansa ja ajatuksensa ystäwällensä - samatekun wirkamiesi halajaa puhella wiransa toimituksesta, maamiesi maansa wiljellyksestä, iloseurassa olija ilostansa ja Murheinen murhestansa - samate waatii myös koko yhteys, koko kansakunta puhella asioistansa, miettiä eduistansa ja sisällisestä elämästänsä. Ilo ja murhe, toiwo ja walitus kaikki waatiiwat hänessä niin kuin yksinäisessäki julkisesti ilmantumista, s. o. yhteisyyttä ja kirjallisuutta." ${ }^{33}$ 
Kanava-lehti (1845-1847) julkaisi kerran viikossa ulkomaan ja kotimaan uutisia, kirjoituksia "kotimaan yhteisissä asioissa" sekä "kuvauksia, jutelmia ja tarinoita kotimaisesta elämästä". Osana ajankohtaista keskustelua lehdessä käytiin debatteja esim. Carl Axel Gottlundin ja Wolmar Schildt-Kilpisen kanssa. ${ }^{34}$

Ilmari Kohtamäki (1959) on ryhmitellyt Kanavan käsittelemät aihepiirit. Pääaiheina olivat kieli- ja kansallisuuskysymykset. Lisäksi lehti julkaisi kaunokirjallisuutta, runoja, näytelmiä ja novelleja. Hannikaisella oli vanhojen ja uudempienkin lehtimiesten kohtalo kirjoittaa vajaat lehdet itse täyteen. Näin Hannikainen sai toisaalta julkaisuväylän omille näytelmilleen ja niiden sisältämälle yhteiskuntakritiikille.

Hannikaisen kaunokirjallisella tuotannolla, näytelmillä ja novelleilla on erityinen kulttuurihistoriallinen arvonsa. Hän alkoi näet julkaista näytelmiä samoilla vuosikymmenillä, jolloin Helsingissä kirjoitettiin ensimmäiset kotimaiset näytelmät ruotsiksi ja kaupungin teatterielämä muutenkin vilkastui. Ennen Hannikaisen näytelmiä oli suomeksi ilmestynyt Juteinin näytelmien ohella vain Koitsanlahden hovissa asuneen majuri J. F. Lagervallin (1787-1865) kirjoittamat neljä pientä näytelmää ja niitä laajempi Macbethin mukaelma Ruunulinna (1834). ${ }^{35}$

Kanavassa ilmestyneistä Hannikaisen näytelmistä ensimmäinen oli Silmänkääntäjä eli Jussi Oluvisen matka Hölmölään. Sen Hannikainen kirjoitti jo vuonna 1838 , mutta Kanavassa se julkaistiin maalis-huhtikuussa 1845 ja kirjana vuonna 1847. Näytelmää esitettiin nähtävästi ainakin Lappeenrannan raatihuoneella 1846, minkä jälkeen sitä tiedetään esitetyn Kuopiossa, Oulussa, Ristiinassa, Yläneellä, Helsingissä ja Viipurissa. ${ }^{36}$ Kirjoittaja itse näki sen vasta vuonna 1859 Viipurissa. ${ }^{37}$ Toisen näytelmänsä, Sukuylpeyden, Hannikainen julkaisi kesällä 1845 Kanavassa, mutta sitä ei tiettävästi ole esitetty. ${ }^{38}$ Anttonius Putronius eli Antti Puuronen julkaistiin vuoden 1846 alkupuolella ja sitäkin esitettiin. Häijyn kriittinen Joululahjukset julkaistiin vuodenvaihteen 1846-1847 numeroissa eikä sitäkään ole esitetty. ${ }^{39}$

Komedian kirjoittajana Hannikainen oli pikemmin satiirinen kärjistäjä kuin sovinnollinen tasoittaja. Silmänkääntäjän farssimaisessa keskiosassa Liisa ja Jussi Oluvinen huijaavat ja rahastavat Hölmölän asukkaita muka taikomalla esiin eläimiä. Yhteiskunnallisesti merkittävämpiä ovat kuitenkin ne kohtaukset, jossa Jussi ja Liisa Oluvinen esiintyvät kaupungin herraskaisina Oluveliiniuslandereina ja muun ohella vaativat kievarissa komeaa kohtelua tai nauravat kansan tyhmyydelle. Nuoren miehen säälimättömin ottein kirjoitettu farssi levisi nopeasti harrastajien piirissä. Silmänkääntäjää esitettiin säätyläisten seuranäytännöissä ja myöhemmin Suomalaisessa Teatterissa. Julius Krohn kiitteli kirjallisuushistoriassaan (1897) näytelmää tasapuoliseksi, koska se ruoski yhtä lailla talonpoikia kuin herrassäätyäkin. ${ }^{40}$ 
Rahvaan hienostelu kuului myös Antti Puurosen (Antonius Putronius) motiiveihin. Näytelmä on melko tarkka suomennos, mutta samalla myös tuohon aikaan tavallinen paikallistaminen, jossa Tanskan ja Norjan kansalliskirjailija Ludvig Holbergin (1684-1754) Erasmus Montanus (Rasmus Berg) on siirretty Suomeen. Nimihenkilö Antti joutuu valitsemaan, luopuako "wilosofiasta" vai rakastetustaan Elisabethista, sillä tämän saadakseen hänen pitäisi kieltää, että maa on pyöreä. Kyläläisten enemmistö on pannukakkuteorian kannattajia. Näytelmän lopussa Puuronen selviää sotaväen pakkovärväyksestä myöntämällä, että "maa on niin litteä kuin kakkara." 41

Kiinnostava detalji on repliikinvaihto, jossa pitäjän lukkari kuulustelee opiskelijalta, kuka Helsingissä on "imprimaturina [painotarkastajana] kirjoille ja lauluille joita präntätään”, mutta tämä ei ymmärrä tai ole ymmärtävinään kysymystä. Näin näytelmässä käsitellään myös Hannikaiselle ajankohtaista sensuuriasiaa. ${ }^{42}$

Hannikainen nosti kahdessa muussakin näytelmässä keskiöön säätyjen välisen jännitteen. Sukuylpeydessä (1845) köyhtyneen aatelisen Kerskoniuksen tytär on lähtenyt kotiopettajaksi ja mennyt naimisiin suomalaisen talonpojan kanssa. Isä kauhistelee tyttären suomikiihkoisuutta, joka on tarttunut myös hänen ulkomailla opiskelleeseen poikaansa. Näytelmän viimeisessä kohtauksessa isä ymmärtää, että hänen on välttämätöntä palauttaa sovinto lasten kanssa. Lajiltaan näytelmä on Rührstück, tunteellinen kappale, jossa konflikti päättyy liikuttavaan sovintoon. ${ }^{43}$ Neljännen näytelmän, Joululahjusten (1846-1847), päähenkilö ryöstövouti Korppi taas on pitkälle viety karikatyyri virkamiehestä, joka kohtelee rahvasta huonosti ja sekoittaa virkatoimiin omia pyyteitään. Korppi muun ohella ilmaisee harminsa talonpojille suunnatuista uusista sanomalehdistä. Monimutkaiset juonittelut eivät pääty Korpin suunnittelemalla tavalla. ${ }^{44}$

Sukuylpeys ja Joululahjukset ovat fennomaanisen kertomuksen aktiivisia unohduksia: ne olivat yhteiskuntaharmoniaa tavoitelleille säätyläisfennomaaneille liian osoittelevia. Hannikainen kuvasi ylemmän luokan hahmot melodraaman konnina, mikä ei ollut mukavaa säätyläistaustaisille ylioppilaillekaan. Julius Krohn ei mainitse näitä kahta näytelmää kirjallisuushistoriassaan (1897) lainkaan, mikä voi olla teoksen toimittajan, Kaarle Krohnin valinta. Unohdusta voi selittää myös teosten dramaturginen yksioikoisuus. Sen sijaan Hannikaisen kaksi muuta, harmittomampaa näytelmää jäivät historiankirjoihin. Kappaleita tekivät Helsingissä tunnetuiksi viipurilaiset ylioppilaat, jotka alkoivat 1850-luvulla esittää suomenkielisiä näytelmiä. Heidän toimintansa sijoittuu osaksi ylioppilaiden parissa laajasti virinnyttä teatteriharrastusta, joka oli muissa osakunnissa ruotsinkielistä. ${ }^{45}$ 
Hannikaisen proosatuotannollakin on arvonsa. Hän kirjoitti yhden varhaisimmista suomenkielisistä historiallisista novelleista Torkel ja Viipurin linna (1845). Vuonna 1847 ilmestyi Viron satuja ja seuraavana vuonna kertomus Serkukset. Myöhemmin Hannikainen suomensi ulkomaisia näytelmiä Suomalaisen Teatterin ohjelmistoon.

Kanavan merkitystä modernin lehdistön uranuurtajana kuvastaa sekin, että lehdessä ilmestyivät ensimmäiset suomenkieliset kirja- ja teatteriarvostelut. Vastaavanlaisia Topelius laati ruotsiksi Helsingfors Tidningariin. Hannikainen julkaisi Kanavassaan kritiikin P. J. Delandin seurueen syksyllä 1846 esittämästä Hamletista. ${ }^{46}$

Kanava antoi kansanvalistusasioissa sivustatukea VSKS:n toiminnalle. Siksi se käsitteli pitäjänkirjasto- ja koulukysymyksiä. ${ }^{47}$ Lisäksi kirjoituksia oli esimerkiksi oikeudenkäytöstä, vankeinhoidosta ja köyhäinhoidosta sekä kyytitoimesta, paloavusta, papiston palkkauksesta, ylellisyyskulutuksesta ja raittiusasiasta. Lehden pääteemoihin kuuluivat silti erityisesti teollisuus, kauppa ja innovaatiot - kaikkinainen talouselämän ja elinkeinojen, myös elinkeinovapauden edistäminen..$^{48}$

Venäjän sensuuri salli kirjoitukset valtiota hyödyttävästä maatalouden kehittämisestä. Maataloustietämyksen parantamiseksi lehdessä suositeltiin säätyläisiä perustamaan maanviljelysseuroja, jotka sopivat uusien viljelymenetelmien ja kaikenlaisten maatalouden parannusten levittämiseen. Maataloutta edistävien kirjoitusten parissa saattoi jatkaa Kuopiossa myös J. V. Snellman Maamiehen ystävässään (1844-1855) sen jälkeen, kun hänen Saima-lehtensä joutui lopettamaan. ${ }^{49}$

Turvallisista viljelysteemoista oli lyhyt matka tulenarkaan maanomistukseen ja keskusteluun hyvästä maatilojen koosta. Snellman ehdotti Saimassa, että tiloja pitäisi voida jakaa useammiksi pieniksi tiloiksi, mikä ratkaisisi maaseudun suuren tilattoman väestön ongelman. Viipurin läänissä tilanne oli jonkin verran toisenlainen: Hannikainen oli Kanavassa kirjoittanut jo liian pienestä tilakoosta. Toisentyyppisen, vaikeaksi koetun ongelman muodostivat tietysti lahjoitusmaiden suurtilat. Vuonna 1846 Hannikainen raportoi 40-6o hengen yhtäaikaisesta häätämisestä suurtiloilta ja katsoi sen tuoneen maanteille tavallista enemmän kerjuulla kulkevaa väkeä. Snellmanin tavoin Hannikainenkin kannatti tilojen jakamista, mutta korosti, että lohkottujen tilojen piti olla riittävän suuria, koska etäämpänä kaupungeista sijaitsevilla tiloilla oli niukasti mahdollisuuksia sivuansioihin. ${ }^{50}$

Viipurin läänissä maanomistuskysymys oli muuta Suomea arkaluontoisempi, koska se kytkeytyi venäläisen aateliston oikeuksiin. ${ }^{51}$ Siksi kuvernööri Casimir von Kothen ${ }^{52}$ raivostui saatuaan tietää, että kyseinen Saiman kirjoitus 
oli alun perin ilmestynyt suomenkielisessä sanomalehdessä hänen omassa läänissään. Von Kothen, joka ei ymmärtänyt suomea, vaati tekstit vastedes käännettäviksi ruotsiksi tai saksaksi. Borgå Tidningissä julkaisemassaan vastineessa hän totesi, että kurjuutta aiheutti nimenomaan suurtilojen pilkkominen. ${ }^{53}$

Von Kothen olisi ilmeisesti ollut valmis lopettamaan koko Kanavan, mutta ratkaisikin ongelman nimittämällä läänin sensoriksi Jacob Judénin. Suomen kielen esitaistelija otti tehtävän vastaan ja sensuroi Pietari Hannikaisen Kanava-lehteä kesäkuun 1846 alusta sen lopettamiseen asti joulukuussa $1847 .^{54}$

Syksyllä 1846 Judén sensuroi Puolan aateliston ja talonpoikien maanomistusoloja käsittelevän kirjoituksen estämällä Finlands Almänna Tidningissä olleen ruotsinkielisen kirjoituksen julkaisemisen suomeksi. Maanomistusoloja saattoi kyllä käsitellä ruotsiksi, mutta ei suomeksi - niin kuin Venäjällä niistä voitiin kirjoittaa saksaksi tai ranskaksi, mutta ei missään tapauksessa venäjäksi. ${ }^{55}$ Kanavan kirjoittelu maanomistuksesta jatkui silti Laatokan rannikkoseutua koskevassa tekstissä, josta siitäkin määrättiin poistettavaksi keskeisiä osia. Muutama muukin kirjoitus ilmestyi vuoden 1847 lehdessä pyyhittynä joko osin tai kokonaan. Tyhjiksi jääneisiin kohtiin Hannikainen sijoitti palstantäytteeksi nimimerkki "Mielenmittaajan" kommentteja tai sopivan monimielisen runon. ${ }^{56}$

Kanavan lakkaamisen syyksi on väitetty sensuurin aktiivisuutta tai kuvernöörin mahtikäskyä. Päätelmä on osin perustunut Hannikaisen omaan lausumaan neljää vuosikymmentä myöhemmin: "Alituiset rettelöt pakottivat lehden taukoamaan." Myöhemmät kirjallisuudenhistoriat ja varsin tuorekin tutkimus ovat toistaneet tätä "sankarillista lopetusta". Toisaalta jo Ilmari Kohtamäki (1959) totesi taloudellisen tappiollisuuden lehden lakkauttamisen varsinaiseksi syyksi. Lehden todellinen ja potentiaalinen tilaajakunta oli suppea, vaikka talouden alamäkeä luultavasti vauhditti osaltaan virkaintoinen "nöyrin palvelija”, sensori Judén.

Kulttuurihistorian näkökulmasta sanomalehden tilaajakannan voi määrittää joukkoistetuksi mesenoinniksi. Taideteoksen ostaessaan tai tilatessaan yksityinen mesenaatti peilaa omaa itseymmärrystään suhteessa artefaktiin. Tilaajan maksama sanomalehti käy keskustelua ja luo heijastuspintaa tämän kehittyvälle itseymmärrykselle.

Vuoden 1847 lopussa Kanavan toimittaja kehotti lukijoitaan kannattamaan Helsingissä vastikään perustettua Suometarta, joka tavoitteli valtakunnallista asemaa. Mutta Viipurissa ryhdyttiin saman tien valmistelemaan uutta Sanan Saattajaa Viipurista, josta laadittiin valmis näytenumerokin. Hanke kariutui, koska von Kothen ilmoitti, ettei hän missään tapauksessa sallisi suomenkielisen lehden julkaisemista Viipurissa, sillä sellaista ei tarvittaisi. Näihin aikoihin 


\section{JAC. JUDÉN JA SENSORIN TOIMI}

Maistraatinsihteeri Judénin vaikuttimia hänen ottaessaan vastaan sensorin tehtävät on ollut vaikea ymmärtää kansallismielisessä historiankirjoituksessa tai jos hänet muuten on haluttu nähdä "sankarillisena suomalaisena" tai "kansan esitaistelijana”. Päätöstä on ihmetelty tai surkuteltu. Kanavaa tutkineelle Ilmari Kohtamäelle (1959) koko asia oli "paradoksaalinen". Voidakseen ylistää Judénia Kohtamäki vakuutti lukijalle virkamieseetoksen näkökulmasta, että tämä pyrki olemaan huolellinen ja täyttämään tehtävät pikkutarkasti. Judénin eron toimesta hän selittää reaktioksi kuvernööri Casimir von Kothenin"mielivaltaisuutta” vastaan ja päättelee, että Judén ilman muuta tuli palvelleeksi "ihanteilleen vieraita tarkoitusperiä". Näin hän rakensi myöhempien sortokausien ihanteille rinnakkaista mielikuvaa pakon edessä suoraselkäisenä pysyneestä virkamiehestä. ${ }^{57}$

Tohtori Judén saattoi kuitenkin suhtautua nuoremman sukupolven säätyvastakohtia korostavaan jyrkkään fennomaniaan varautuneesti. Jos von Kothenin silmissä nuori Pietari Hannikainen oli levottomuutta herättävä henkilö, hän saattoi olla sitä myös keski-iän jo ylittäneen Judénin silmissä. Von Kothenin luottamus Judénia kohtaan käykin ilmi eräästä hänen kirjekatkelmastaan: "Tohtori Judén, jonka mielipiteet olivat minulle tuttuja [--] voi ja haluaa käsittää minun hänelle antamiani ohjeita."58
Judén tuskin 65-vuotiaana saattoikaan kieltäytyä luottamustehtävästä, josta maksettiin hyvä palkkio. Näissä tehtävissä palvelivat usein oppineet ja yliopistomiehet. $^{59}$

Judén saattoi ajatella voivansa painotarkastajana edistää suomen kielen asiaa, sillä Hannikaisen kärjekkäät hyökkäykset virkakuntaa vastaan olisivat voineet hidastaa ylempien säätyjen kääntymistä myötämielelle kansankieltä kohtaan. Menemällä puskuriksi väliin hän mahdollisti Hannikaisen työn ja saattoi antaa hänen julkaista niin rohkeasti kuin oli kohtuudella mahdollista. Oletusta voi nimittää valistuneen sensorin dilemmaksi.

Vanhan Hannikaisen happaman kommentin mukaan tämä Viipurin "uusi sensori oli ehkä [edellistä] taipuvaisempi noudattamaan arwoisan paronin [von Kothenin] ohjeita. Hän asui aiwan vastapäätä maaherran asuntoa ja saattoi joka pulassa juosta kadun poikki." ${ }^{\circ 0}$ Myös kustantaja A. F. Cederwaller valitteli uuden sensorin kiivautta. ${ }^{61}$ Siinä katsannossa Kohtamäen päätelmä Judénin hyvästä virkamiesmoraalista voikin osua oikeaan. Moraalisen tuomion langettaminen on yhtä tarpeetonta kuin historiallisten henkilöiden toiminnasta yleensäkään. Viipurin läänin sensoriksi ei ollut valittavaksi ketään toista suomentaitoista miestä, joka olisi ollut yhtä lähellä ylintä hallintokoneistoa tai johon von Kothen olisi luottanut. 
Judén erosi painoasiamiehen tehtävästä mahdollisesti protestoidakseen von Kothenin liian tiukkaa kantaa vastaan. ${ }^{62}$

Lehtihankkeen kariutuminen ei lannistanut Hannikaista, joka löysi uusia kanavia. Hän kirjoitti sanomalehtiin novelleja ja julkaisi käytännöllisen opaskirjan Asianajaja eli lain-opillinen käsikirja Suomen kansalle (1847). ${ }^{63}$ Hannikainen jatkoi tiedon ja valistuksen jakamista toimittamalla Lukemisia maamiehille -lehteä (1849-1851), jota julkaisi Maanwiljeliäin Seura Wiipurissa. Niin ikään Hannikainen avusti Suometarta, jonka toimittajaksi hän sittemmin siirtyi Helsinkiin. ${ }^{64}$

Juteini ja Hannikainen olivat kiistatta tunnetuimmat viipurilaiskirjailijat, jotka julkaisivat suomeksi jo ennen 180o-luvun puoliväliä. Näistä kahdesta suuremman jälkimaineen sai Juteini, jonka julkaisutoiminnan painopiste oli varhaisemmissa vuosikymmenissä ja kaunokirjallinen tuotantokin luultavasti Hannikaisen tuotantoa laajempi. ${ }^{65}$ Yrjö Koskisen johtaman kulttuurityön tuloksena luotu suurmiesten kaanon ei Hannikaista erityisesti tarvinnut. Toki tämä liberaali ja radikaali lehtimies luettiin kuolemansa aikaan (1899) silti suomenkielisten pioneereihin. ${ }^{66}$

\section{LEHTIKUSTANNUS, PÄÄTOIMITTAJUUS JA KIRJAILIJANTOIMI - YLEISMIESTEN VUOSIKYMMENET}

Harva jos kukaan säätyläiseksi syntynyt pystyi vielä 180o-luvun alkupuolella kirjoittamaan suomeksi. Herrasmiehen kuului kyllä osata kirjoittaa kaunokirjallisuutta tai jopa historiallinen draama, ja oppikoulujen äidinkielen tunneilla harjoiteltiin runomittojen kirjoittamista ja novellien sepittämistä. Opinkäynnin kielenä olivat tuolloin ruotsi tai saksa, mutta hankittuja kirjoittajan taitoja ei ollut helppoa soveltaa suomeksi. Ennen kansallista herätystä sujuvan suomen omaksuivat säätyläisistä lähinnä vain Sisä-Suomen maaseudulla kasvaneet pappien ja virkamiesten lapset. ${ }^{67}$

Suomenkielisille kansankirjoittajille sen sijaan tarjoutui 1830-1840-luvuilla julkaisuväyliä muun muassa viipurilaisissa sanomalehdissä. Myöhemmin Jyväskylän (per. 1863) ja Sortavalan (per. 1880) opettajaseminaarit tarjosivat esimerkiksi käsityöläistaustaisille kansanmiehille opintien, joka avasi heille mahdollisuuksia puoliammattimaiseen kirjoittajantyöhön.

Suomeksi kirjoittaneita maisteris- ja tohtorismiehiä toimi 180o-luvun Viipurissa useita. Osa oli Viipurissa syntyneitä, osa siellä kasvaneita, osa päätynyt työskentelemään kaupungissa. Nämä ansaitsivat leipänsä lehtimiehinä, opettajina ja suomentajina, sillä kaunokirjailijan ammatista yksinomaisena leipäpuuna miltei kaikki heistä ymmärsivät olla haaveilematta. Tunnetuin suoma- 
lainen poikkeus tästä oli Aleksis Stenvall (1834-1872), joka olisi hänkin toivonut saavansa Uudellamaalla pehtorin tai metsänhoitajan työtä toimeen tullakseen.

Viipurissa itsenäisen kirjallisen toimijan uraa yritti Johannes Alfthan (18301893). Merkittävään viipurilaiseen kauppias- ja sotilassukuun kuuluneen Alfthanin isä oli teollisuudenharjoittaja, joka oli perustanut muun muassa Havin kynttilätehtaan. Helsingissä 1840-luvun lopulla opiskellut Alfthan kuului Viipurilaisen osakunnan liberaaleihin ja kirjallisiin aktivisteihin, jotka täyttivät osakunnan ruotsinkielistä lehteä kirjallisuusessein ja kiistakirjoituksin. Viipuriin hän palasi jouduttuaan eroamaan yliopistosta, koska hän oli levittänyt radikaaleja ajatuksia. ${ }^{68}$ Taustan vakavaraisuus loi Alfthanille varmuutta ryhtyä kirjapaino-, sanomalehti- ja kirjankustannusalalle, mutta samalla aatteellisuus nähtävästi helli epärealistisia kuvitelmia taloudellisen menestymisen mahdollisuuksista.

Alfthan osti Cederwallereilta kirjapainon, perusti Viipuriin kirjakaupan ja ryhtyi opiskelutoverinsa tohtori C. I. Qvistin (1827-1897) kanssa julkaisemaan uutta sanomalehteä. ${ }^{69}$ Heidän lehtensä Wiborg. Tidning för litteratur, handel och ekonomi (1855-1861) nousi nopeasti valtakunnallisesti tunnetuksi ja sai aseman uusien liberalististen ajatusten äänitorvena. Wiborg nähdään Suomen lehdistöhistorian ensimmäiseksi vapaamieliseksi ja kriittistä journalismia harjoittaneeksi lehdeksi. ${ }^{70}$ Sen rinnalla Viipurissa ilmestyi suomenkielinen Sanan-Lennätin (1856-1858), ehkä Aamurusko (1857-1859) ja sittemmin VSKS:n julkaisema Otava (1860-1863). ${ }^{71}$ Venäläisillä sen sijaan ei koskaan ollut Viipurissa omaa sanomalehteä. ${ }^{72}$

Qvistin ja Alfthanin liberalismille oli ominaista, ettei kansallinen identiteetti ollut suoranainen kielikysymys. Pietarin läheisyys, samoin kuin Viipurin monikulttuurisuus ja yhteydet maailmalle tekivät itäisestä Suomesta läntistä Suomea avoimemman kansainvälisille virtauksille. ${ }^{73}$ Wiborgin kirjoituksissa edistettiin kansankielen asemaa, mutta ne olivat alisteisia laajemmille muutosvaatimuksille, jotka koskivat yhteiskunnan rakenteiden uudistamista, kaupan ja teollisuuden esteiden poistamista ja vapautumista kaikesta holhoamisesta. Tämän uskottiin hyödyttävän kansakuntaa ja luovan luonnolliset edellytykset myös kansankielen aseman parantumiselle. ${ }^{74}$

Viipuri eli dynaamista vaihetta 1850-luvulla, jolloin Turun merkitys oli vähentynyt eikä Helsinki ollut vielä noussut niin dominoivaan asemaan kuin vuosikymmentä myöhemmin. Keskisen ja itäisen Suomen kehittämiseksi Wiborgissa ehdotettiin Päijänne-Saimaa-kanavan rakentamista, mikä olisi korostanut Viipurin kaupallista merkitystä vielä entisestään. ${ }^{75}$ Kaavaillut rautatielinjat taas olisivat edistäneet Viipurin kosmopoliittisen hengen valjastamista koko Suomen hyödyksi. ${ }^{76}$ 
Wiborg-lehden mukaan kansallishengen leviäminen piti saada osaksi yleistä reformipolitiikkaa ja samalla kansan omaksi asiaksi, ei vain sille vieraita tavoitteita ajaneiden sivistyssäätyjen ohjelmaksi. Tässä asiassa Viipurin radikaalit Alfthan ja Qvist joutuivat kiistaan Yrjö Koskisen kanssa jo vuonna 1856. ${ }^{77}$ Qvist ja Alfthan jättivät lehden joidenkin vuosien jälkeen toisiin käsiin, jolloin lehden tilaajakunta viimeistään alkoi hiipua. Se lopetettiin kuuden toimintavuoden jälkeen. ${ }^{78}$

Johannes Alfthan oli Viipurin kasvatti ja monitoiminen uudistusmies, joka kirjoitti pääasiassa ruotsiksi. Varhaisten runokokoelmien Italine (1850) ja Molnbilder (1853) jälkeen hän tosin julkaisi kymmeniä lapsille suunnattuja kertomuksia oman kirjapainonsa Aamurusko-lehdessä Hannikaisen toimittamana ja mahdollisesti suomentamana. Koettuaan taloudellisia takaiskuja ja menetettyään vaimonsakin Alfthan muutti kahden vanhimman poikansa kanssa Ruotsiin. Vuonna 1860 kirjapainon osti lehtori N. A. Zilliacus. ${ }^{79}$ Ruotsissa Alfthan yritti elättää itsensä kirjailijana, aiheenaan Viipurin ja muun Itä-Suomen elämä. Hän julkaisi teokset Viborgska smällen (1870), Noveller och skizzer (1872), En sommarsaga från Finland (1872), Den förmodade nihilisten, berättelse (1882) ja Ett gottgjordt ungdomsfel (1892), jotka jäivät vaille laajempaa lukijakuntaa. Hän kuoli unohdettuna Ruotsissa. ${ }^{80}$

Alfthania vuosikymmenen vanhempi mies oli puolalais-savolaistaustainen Rietrikki (Fredrik) Polén (1823-1884), joka vaikutti Viipurissa Alfthania myöhemmin. Polénia oli pidätellyt Helsingissä muun ohella ensimmäisen suomenkielisen väitöskirjan (1858) valmistelu. Väitöskirjan aiheena olivat varhaisen suomenkielisen kirjallisuuden aikakaudet. Viipurissa Polén työskenteli vuosina 1868-1874 lukion suomen kielen lehtorina, lehtimiehenä ja kirjailijana. VSKS:n esimiehenä hän sai runojaan julki suhteellisen helposti: Kirjallinen aarreaitta ilmestyi vuonna $1869 .{ }^{81}$

Alfthanin ikätovereita puolestaan oli Kaarlo Slöör (1833-1905), viipurilaisen sepän poika, joka valmistui maisteriksi 1857. Hän sai Pietarista viran kansakoulujen tarkastajana ja laati oppikirjojakin, mutta siirtyi 186o-luvun puolivälissä Helsinkiin toimittamaan Julkisia Sanomia ja Virallista lehteä. Tämän tehtävän rinnalla hän toimi myöhemmin kenraalikuvernöörin kanslian virassa. 1850-luvulla Slöör oli kerännyt kansanrunoja ja kirjoittanut runoja nimellä Kaarlo Santala. Omaa kirjallista tuotantoa merkittävämmäksi on nähty hänen ansionsa suomentajana, esimerkkinä vuoden 1860 SKS:n kilpailuun käännetty Eugène Scriben komedia Ensimmäinen rakkaus (julk. 1861). Tunnetuimpia ovat Shakespearen Macbeth 1864 ja Ibsenin näytelmät (Nora, eli Nukkekoti 1880).

Viipurissa virinneen suomenkielisen kulttuurin tunnetuimpia hahmoja oli kuitenkin Julius Krohn (1835-1888), jonka äiti oli vanhaa Dannenbergin kauppiassukua. Isän saksalainen suku taas oli tullut Pietarin kautta Suomeen. 


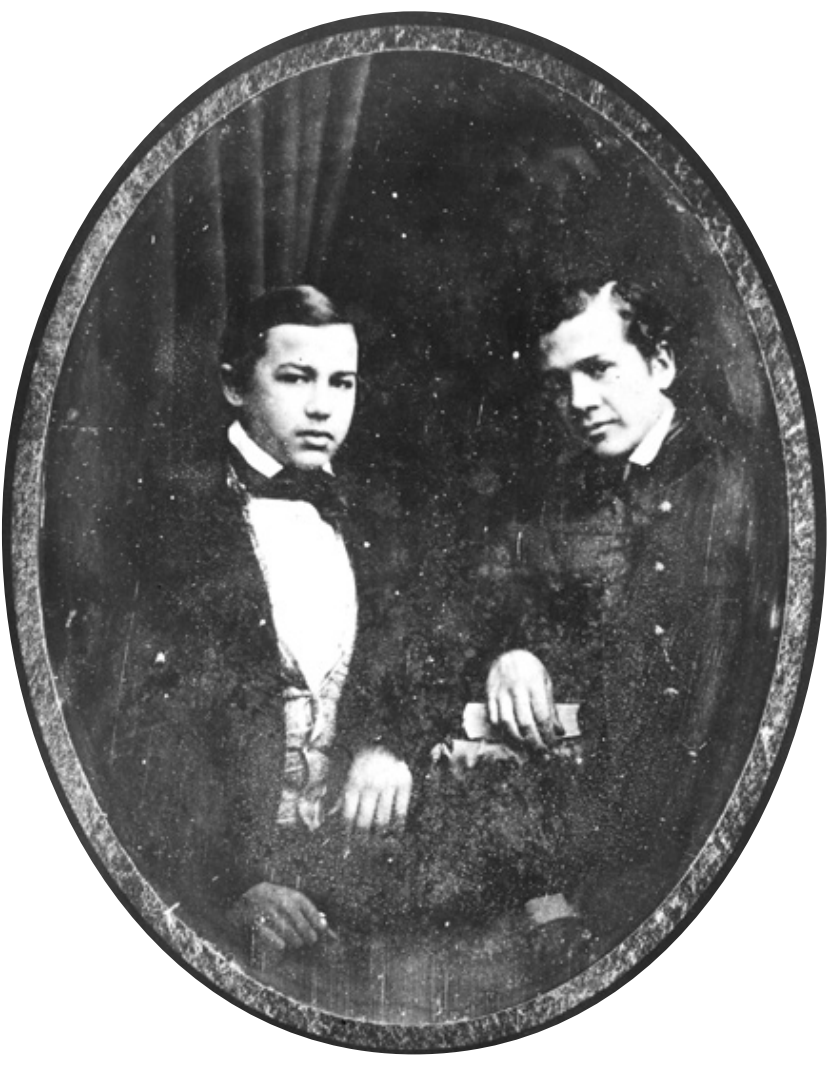

Nuoret veljekset Julius ja Leopold Krohn yhteiskuvassa noin vuonna 1850.

Juliuksen ensimmäinen kieli oli saksa, varhaiset kotiopettajat taas olivat venäjän ja ranskankieliset, mutta palveluskunnan kanssa puhuttiin suomea ja ruotsia. Varakkaan kauppiaan poikana ja Kiiskilän kartanon kasvattina Krohn kuului säätyläistöön, mutta ei aateliin. Hän kävi Viipurin ruotsinkielisen lukion, jonka ilmapiiri oli hänen kouluvuosinaan isänmaallinen. Opettajista suomalaisuusinnostusta herättelivät erityisesti C. W. Ahrenberg, C. H. Ståhlberg ja K. H. J. Ignatius. Suomen opetukseen Krohnin täytyi erityisesti perehtyä, sillä hän ei osannut kieltä niin hyvin lapsuudestaan kuin muut. Krohnista kasvoi poikkeuksellisen kielitaitoinen. Koulutoverinsa Kaarlo Slöörin kanssa Krohn päätti opiskeluvuosina Helsingissä käyttää keskustelukielenään suomea. ${ }^{82}$

Krohn valmistui lisensiaatiksi vuonna 1862 ja jatkoi siitä, mihin Polén jäi, nimittäin tämän väitöskirjaa laajemman suomenkielisen kirjallisuuden historian kirjoittamista. Se ilmestyi Kaarle Krohnin toimittamana postuumisti vasta vuonna 1897. Julius Krohn toimi myös runoilijana - nimellä Suonio - sekä useamman helsinkiläisen lehden toimittajana ja lopulta yliopiston suomen kielen lehtorina. Tuore professuuri (1885-1888) katkesi traagiseen purjehdusonnettomuuteen ja hukkumiseen Viipurinlahdella. Tämäkin tapahtuma sitouttaa hänet Viipurin maisemaan, vaikka suku sen jälkeen luopui Kiiskilän kartanosta.

Julius Krohn aloitti sen Kalevalan alkuperäisten runojen tutkimusperinteen, jossa hänen pojastaan, professori Kaarle Krohnista tuli kansainvälinen folkloristiikan uranuurtaja. Julius Krohnin jälkikasvu on toiminut laveasti suomenkielisessä kulttuurissa: Aino Kallaksesta tuli kuuluisa kaunokirjailija, Ilmari Krohnista musiikkitieteilijä ja professori ja Helmi Krohnista kirjailija, toimittaja ja päätoimittaja (Pääskynen, Valvoja), joka muun ohella kirjoitti kotimaisten naistaiteilijoiden elämäkertoja. Myös Aune Krohn suomensi ja kirjoitti. Niin Krohnin suvun ”juliaanit” kuin Juliuksen veljen Leopoldinkin jälkeläiset, ”leo-

116 | SUOMENKIELISEN KIRJALLISUUDEN KAUPUNKI 
poldiaanit”, vaikuttavat edelleen monin tavoin suomalaisilla elämänaloilla. ${ }^{83}$

Myös kirjoittavia käsityöläisten poikia ja muita "rahvaan runoniekkoja" tai "kansankirjailijoita" asui Viipurin seudulla ja jotain heidän tuotannostaan VSKS julkaisi. ${ }^{84}$ Julius Krohn ihmetteli kirjallisuushistoriassaan, kuinka monet Suomen kansanomaisista kirjoittajista - ja akateemisen opintien käyneistäkin kansankielisistä kirjailijoista - olivatkaan kotoisin Itä-Suomesta:

\footnotetext{
Hyvin merkillistä on, että suurin osa tämän ajan lauluniekoista on kotoisin "Vanhasta Suomesta”. Näyttää siltä kuin tämän saksalaistuneen osan maatamme vasta yhteinen herännyt suomalaisuuden aate olisi muuhun Suomeen henkisesti yhdistänyt ja äkkiä purkanut esiin siinä kauan pidätetyt tunteet. Paitsi Pietari Hannikaista, on meille täältä tullut Konstantin Schröder ${ }^{85}$, Pietari Mansikka, Antti Räty, Kaarlo Slöör, Aleksanteri Rahkonen, Olli Berg eli Vuorinen ja Arvi Genetz eli Jännes. ${ }^{86}$
}

Samaa kysymystä tarkasteli myös Kustavi Grotenfelt kokoelmassaan Kahdeksantoista runoniekkaa (1889), joka oli yhteenveto tuolloisista kansankirjoittajista. Hänen mukaansa Itä-Suomessa osattiin vielä hyvin kalevalamittaa, jota moni kokoelmassa esitellyistä runoilijoista käytti taitavasti. Kansankirjailijoiden antologian tehtävänä oli osoittaa, miten kyvykkäitä kirjoittajia ja kielen käyttäjiä suomenkielisen rahvaan parissa kasvoi ja millaista taiteellis-kirjallista lahjakkuutta sieltä löytyi. ${ }^{87}$

Krohnin edellä mainitsemista kansankirjoittajien vanhimmasta polvesta yhteys Viipuriin oli Pietari Mansikalla, Antti Rädyllä ja Olli Vuorisella. Pietari Mansikka (1825-1871) oli talollisen poika Viipurin maalaiskunnasta, joka muun ohella avusti Sanan-Lennätintä vuosina 1856-1858. Käkisalmelainen Antti Räty (1825-1852) puolestaan toimi Pietarissa opettajana ja suomentajana. VSKS julkaisi hänen kokoelmansa Lauluja Suomen neitosille (1850). Myöhempää polvea edusti Olli (Berg) Vuorinen (1842-1917), joka oli talollisen poika Uukuniemeltä. Hänkin työskenteli erilaisissa opettajan toimissa muun muassa Haminassa. Vuorinen aloitti julkaisemalla Otavassa. ${ }^{88}$

\section{0-LUVUN LOPPUPUOLEN KIRJOITTAJIEN VAIHTELEVAT TAUSTAT}

Huomion ansaitsee opettaja, lehtimies, kirjailija ja historioitsija, tohtori Wilhelm Gabriel Laguksen (1837-1896) laaja ja monipuolinen tuotanto. Hän toimi vuodesta 1867 Viborgs Gymnasiumin opettajana ja sittemmin rehtorina. Lehtimiehenä Lagus toimitti alkuun Wiborgs Tidningiä, mutta sai myöhemmin Östra Finlandin tärkeimmäksi kanavakseen liberaaleille ja varsin suvaitseville 
kielipoliittisille näkemyksilleen. Lehdissään hän toimi myös kirjallisuus- ja teatterikriitikkona. Nuoruutensa Helsingissä ja myöhemmin Viipurissa Lagus laati näytelmät Terzerola (1857), Klubbhövdingen, En julafton i Tobolsk, Drottning Filippa (1870), I natten, Den nya adjunkten (1881), jotka kaikki pääsivät esitettäviksi Nya Theaterniin (Ruotsalainen Teatteri). Hänellä oli myös runotuotantoa. Lagus suuntautui tietokirjailijana historiallisesti: hän kirjoitti paitsi katsauksen Suomen ruotsinkielisestä kirjallisuudesta (Den Finsk-Svenska Litteraturens Utveckling I-II, 1866-1867) myös ensimmäisen laajan tutkimuksen Viipurin historiasta (Ur Viborgs historia I-II, 1893-95) sekä laati muun ohella tutkielmia ja kouluhistorioita. Suomenkielinen historiankirjoitus on lähes sivuuttanut Laguksen kulttuuri- ja sivistyshistoriallisesti merkittävän työn.

Viipurin suomenkielisten maisterikirjailijoiden ryhmään voidaan lukea myös monia opintojen jälkeen Viipuriin tai muualle Itä-Suomeen palanneita kynäniekkoja. 1840-luvulla syntyneitä Viipurin kymnaasin ylioppilaita (1862) oli Aleksanteri Rahkonen (1841-1877), jonka taitoja runouden notkeana suomentajana monet lehdet hyödynsivät. Hän käänsi ja sovitti myös näytelmiä ja musiikkinäytelmiä (1868-1873) ja osallistui Vänrikki Stoolin tarinoiden suomennosryhmän työhön. Hän palasi Viipuriin ja toimi sittemmin opettajana Uuraassa ja Pietarissa, kunnes kuoli varhain keuhkotautiin..$^{89}$ Kai Laitisen vuonna 1981 ilmestyneessä Suomalaisen Kirjallisuuden historiassa sen paremmin Polénilla, Slöörillä kuin Rahkosella ei ole enää sijaa - siksi suppeaa kaikkien kolmen tuotanto oli.

Myös Suomalaisen Teatterin (1872) perustaja ja johtaja Kaarlo Bergbom (18431906) oli syntynyt Viipurissa ja asui hovioikeuden asessorin poikana kaupungissa ensimmäiset elinvuotensa. Bergbomin suppeaan kirjalliseen tuotantoon kuuluu novelli "Sydämmiä ihmistelmeessä" (Hjärtan i menskovimlet, 1869), joka sijoittuu ”W:n kaupunkiin Itä-Suomessa". Se alkaa satiirina provinssi- ja varuskuntakaupungin seuraelämästä, mutta asettaa pian analogisesti rinnakkain kaksi kansallistunnetta. Suomalainen kanteleensoittajatar kirvoittaa puolalaisen säätyläisrouvan laulamaan puolalaista kansanlaulua: kaipuu ja surumieli ovat yhteisiä. ${ }^{90}$

Samaan ikäpolveen ja säätyläistöön kuuluu vielä Arvid Genetz (Arvi Jännes, 1848-1915) runoilija, kielentutkija ja suomen kielen professori ja Bobrikovin ajan senaattori (1901-1905). Vaikka Jännes assosioituu enemmän Laatokan Karjalaan kuin Viipuriin, hänen vahvasti isänmaalliset runonsa ("Herää Suomi", "Karjala", "Karjalan lapset") saivat Viipurissakin merkitystä itsenäisyyshengen rakentajina ja kuorosävellysten aatepohjana.

Bergbomin ja Genetzin kanssa samaan ikäpolveen lukeutuu J. H. Erkko, yksi aikansa tunnetuimmista suomenkielisistä lyyrikoista. Kansakoulunopettaja Juhana Henrik Erkko (1849-1906) oli syntyisin talollisen poika Orimattilasta. Ensimmäiset runonsa Jyväskylän seminaarin oppilaana julkaissut Erkko hank- 
ki elantonsa lähes kahden vuosikymmenen ajan Viipurissa VSKS:n ylläpitämän Wilken koulun opettajana (1874-1893).

Viipurin kausi oli Erkolle huomattavan tuottelias. Hän julkaisi useita runokokoelmia sekä kirjoitti ensimmäiset näytelmänsä Tietäjä (esitetty Suomalaisessa Teatterissa 1888) ja Aino. Ainon ensi-ilta Suomalaisessa Teatterissa helmikuussa 1893 oli valtava menestys ja oikeastaan käynnisti Bergbomin teatterin kansallisromanttisen vaiheen. Ainon katsojien joukossa oli muun muassa Jean Sibelius, joka tilasi Erkolta oopperalibreton. Oopperahanke tosin kariutui, koska siinä ei Bergbomin mielestä ollut riittävästi toimintaa. Muutettuaan Viipurista Erkko jatkoi tuotteliasta runoilijantyötään ja kirjoitti karelianismin vuosikymmenen hengessä näytelmän Kullervo (1895). Erkon runous levisi laajalti myös Oskar Merikannon säveltäminä, huomattavan suosittuina lauluina. ${ }^{91}$

Erkon runouden yksinkertainen kauneus ja laulullisuus miellyttivät tavattomasti köyhistä oloista noussutta kauppaneuvos Juho Lallukkaa (1852-1913). Hän tahtoikin turvata runoilijan olosuhteet sen jälkeen, kun tämä oli jäänyt pois ansiotyöstä voidakseen kirjoittaa laajempia teoksia, kuten kalevalaisia runonäytelmiä..$^{92}$ Tällainen kirjailijantyön mesenointi oli Suomen oloissa vielä poikkeuksellista ja Erkolle todellinen etuoikeus. ${ }^{93}$

Vuosisadan lopun tunnetuimpiin ruotsinkielisiin viipurilaisiin kuului myös Johan Jacob (Jac.) Ahrenberg (1847-1914), arvostettu monitaituri. Viipurin lyseon rehtorin, VSKS:n perustajiinkin kuuluneen Carl Wilhelm Ahrenbergin lahjakas poika opiskeli arkkitehtuuria Tukholmassa ja Etelä-Euroopassa ja omaksui tyylikseen synteesin, joka yhdisti vanhoja tyylejä toistavan historismin puhdaslinjaisuutta tavoittelevaan klassismiin. Hän suunnitteli useita Viipurin julkisia rakennuksia sekä toimiessaan Viipurin lääninarkkitehtina vuosina 1885-1886 että tämän jälkeen. Nuorempi Ahrenberg antoi vahvan panoksen Viipurin historian artikuloimiseen laatimalla näyttävän suunnitelman Viipurin linnan entisöimiseksi Vaasa-kuninkaiden tyyliin. Ehdotus ei kuitenkaan sopinut Venäjän sotaministeriölle, joka linnan omisti. ${ }^{94}$

Ahrenberg kirjoitti paitsi tutkimus- ja esseekirjallisuutta, myös laajan sarjan Viipurin lääniin sijoittuvia novelleja ja kertomuksia, jotka on suomennettu. ${ }^{95}$ Antoisia ovat esimerkiksi elävät, pakinoivaan tyyliin kerrotut ihmiskuvaukset sarjassa Människor som jag känt: Personliga minnen, utdrag ur bref och anteckningar. 1-6. (1904-1914). Ahrenbergin näkemyksiä on pidetty konservatiivisina; ajatusta säätykierrosta hän jopa vieroksui. Hänen kirjallisen maailmankuvansa ytimen muodostivat kansalliselta pohjalta syntyvät sovinnolliset loppuratkaisut. ${ }^{96}$ Erik Ekelundin mukaan Ahrenbergin tuotantoa leimaa jännite, jossa konservatiivinen ihminen rakastaa "isänmaan turvetta" ja romanttinen individualisti kaipaa suureen ja tuntemattomaan maailmaan. ${ }^{97}$ 


\section{KIRJAILIJAN TYÖ AMMATTINA}

Kulttuurihistoriallisen tarkastelun kolmannesta vaiheesta, taiteen tekemisen institutionalisoitumisesta, voidaan puhua silloin, kun kustannustoiminta on jo varsin laajaa ja itsenäistä. Kirjailijoiden on silloin mahdollista valita useiden kustantajien välillä, ja kirjojen myynti perustuu valtakunnalliseen verkostoon. Vaikka kirjailijat eivät vielä olisi järjestäytyneet ammatillisesti, heidän piirissään on jo muodostunut sekä kollegiaalista tietoisuutta että toveruutta. Kirjalliset piirit muodostavat jopa yhteistä mielipidettä, elleivät käy poliittisia taisteluja. Useimmat joutuvat silti edelleen elämään joko hyvin vaatimattomissa oloissa tai tekemään sivutöitä, esimerkiksi toimittamaan sanomalehteä. ${ }^{98}$

Varhaista ammattilaiskirjailijoiden sukupolvea edusti Viipurissa lapsuutensa viettänyt Arvid Järnefelt (1861-1932). Hänen laajassa tuotannossaan ainakin yksi näytelmä, Samuel Cröell (1899), sijoittuu 160o-luvun Viipuriin. Näytelmän päähenkilö kanneviskaali Cröell sai edustaa oikeamielistä ja totuuteen sitoutunutta ihanteellista virkamiestä. ${ }^{99}$ Kaikkien historiallisten näytelmien tapaan se kuvaa yhtä paljon omaa aikaansa kuin käsittelemäänsä aikaa. ${ }^{100}$

Kirjalliseen elämään vaikutti kielikysymyksen ohella puoluemuodostuksen historia, vaikka sen tarkasteleminen ei ole tässä mahdollista. Arvid Järnefelt edusti nuorsuomalaisiin identifioituvaa ryhmittymää. Viipurin ilmapiirin kannalta on lisäksi mainittava kaupungissa kolme vuotta (1885-1888) vaikuttanut Nils Robert af Ursin (1854-1936). Hän oli karjalaistaustaisen aatelissuvun jäsen ja lukion lehtori, joka edisti aktiivisesti Viipurin työväen järjestäytymistä ja yhdistystoimintaa. ${ }^{101}$

Vaikkei af Ursinilla ole kaunokirjallista tuotantoa, hänen merkityksensä sosialismin levitystyössä on huomattava: kahden Viipurissa vaikuttaneen työväenliikkeeseen sitoutuneen kirjailijan ura rakentui hänen työnsä varaan. Toinen heistä oli inkeriläissyntyinen Matti Kurikka (1863-1915), joka asui Viipurissa vuosina 1888-1894 - heti af Ursinin jälkeen. Hänen näytelmädebyyttinsä, maaorjien vapauttamista käsitellyt Viimeinen ponnistus (1884) menestyi Suomalaisessa Teatterissa ja sen kiertueella Viipurissa. Suunnitellut vierailuesitykset Pietarissa kuitenkin kiellettiin, mutta lisäesityksiä järjestettiin Viipurissa, minne inkeriläisiä matkusti näytelmää katsomaan. Kurikan toinen näytelmä Aili (1887) taas käsitteli seksuaalikysymyksiä raflaavalla tavalla. Kaarlo Bergbom kehottikin kuumapäistä kirjailijaa lukemaan sen ensin vaimolleen ja sisarelleen ja tekemään siihen näiden toivomat muutokset. Suomalaisen Teatterin ohjelmistoon näytelmää ei lopulta otettu. ${ }^{102}$ Kurikan muita näytelmiä olivat Äärimmäisessä talossa (1889) ja Baabelin torni (1897), mutta ne eivät enää menestyneet.

Kurikka ryhtyi nuorsuomalaisten Viipurin Sanomien (1888-1894) toimittajaksi ja omistajaksi, mutta lupaavan alun jälkeen lehtimiehen ja kustantajan 
ura Viipurissa päättyi konkurssiin. Vaikka Kurikka esiintyi Viipurin vuosinaan suurisuuntaisesti ja tuhlailevasti, hän lähentyi jo tuolloin paikallista työväkeä ja tuli valituksi Viipurin Työväenyhdistyksen johtokuntaan. Maltillisesta kateederisosialismista teosofis-utopistisen sosialismin tielle Kurikka siirtyi muutettuaan Helsinkiin ja ryhdyttyään Työmies-lehden päätoimittajaksi vuonna 1897. Hän nosti lehden teräväksi poliittiseksi keskustelijaksi. Kurikan opit olivat Suomen oloihin silti liian omalaatuisia saadakseen laajaa vastakaikua. Kurikka siirtyi vuonna 1900 toteuttamaan yhteiskunnallista utopiaansa Kanadaan, mutta kokeilu epäonnistui. ${ }^{103}$

Vuosisadan vaihteen radikaaleihin kuului myös Suomen työväenliikkeen perustajiin kuulunut A. B. Mäkelä (1862-1932). Kustavissa syntynyt Mäkelä oli käynyt Sortavalan seminaarin ja toimi opettajana ja lehtimiehenä muun muassa Viipurin sanomissa 1892-1894. Radikaalina kirjoittajana hän käytti nimimerkkiä "Kaapro Jääskeläinen”. Itä-Suomen yhteiskunnallisiin oloihin kytkeytyi hänen paikalliseen teollisuusyritykseen sijoittuva näytelmänsä Ruukinjaloissa (1896), joka käsitteli työväen lakkosuunnitelmia. ${ }^{104}$

\section{VIIPURI JA MODERNI ELÄMÄ - KERSTI BERGROTH}

Kirjalliset sukupolvet ovat yhteydessä tyylivalintoihin, joihin heijastuvat kirjoittajan yhteiskunnallinen tausta ja kotikasvatus. Uusromantiikan hengessä syntynyt 1900-luvun alun modernismi irrottautui realismin lähtökohdista, etenkin arjen kuvauksesta ja sen yhteiskunnallisesta velvoittavuudesta. Suomalaista modernismia luonnehti lisäksi pyrkimys irrottautumiseen aikansa jyrkistä kielipoliittisista kannoista ja kielen normeista. Erityisesti 1920-luvulla modernistit loivat kollegiaalisia suhteita yli kielirajojen. ${ }^{105}$

Viipurilaista kosmopoliittisuutta tässä modernissa hengessä edusti Kersti Bergroth (1886-1975), joka oli Jac. Ahrenbergin tavoin varttunut rehtorin kodissa. Bergroth valmistui kirjallisuuden maisteriksi, puhui Euroopan tärkeimpiä kieliä (saksa, ranska, englanti) ja suomensi niistä proosaa ja draamaa. Bergroth kirjoitti ammattimaisesti tavattoman laajan ja monipuolisen tuotannon, joka kirjallisuuden kaanoneissa jäi ensin taka-alalle. ${ }^{106}$

Ensimmäisten julkaisujensa perusteella Bergroth voitiin lukea suomenruotsalaisten intellektuellien Dagdrivare-ryhmään, sillä romaanien päähenkilöitä olivat nuoret urbaanit ihmiset. Teosten Augusti (1911), Aptit (1914), Sixtus (1916), Urbans väg (1919) tapahtumat sijoittuivat karjalaisille maatiloille ja huviloille. ${ }^{107}$

Kersti Bergroth alkoi julkaista suomeksi vasta vuonna 1917 ja käänsi tämän jälkeen tuotantoaan molemmille kielille. Nimimerkki Mary Marck julkaisi suomeksi ja ruotsiksi joukon suosittuja, naiskuvaltaan moderneja koululaisromaa- 


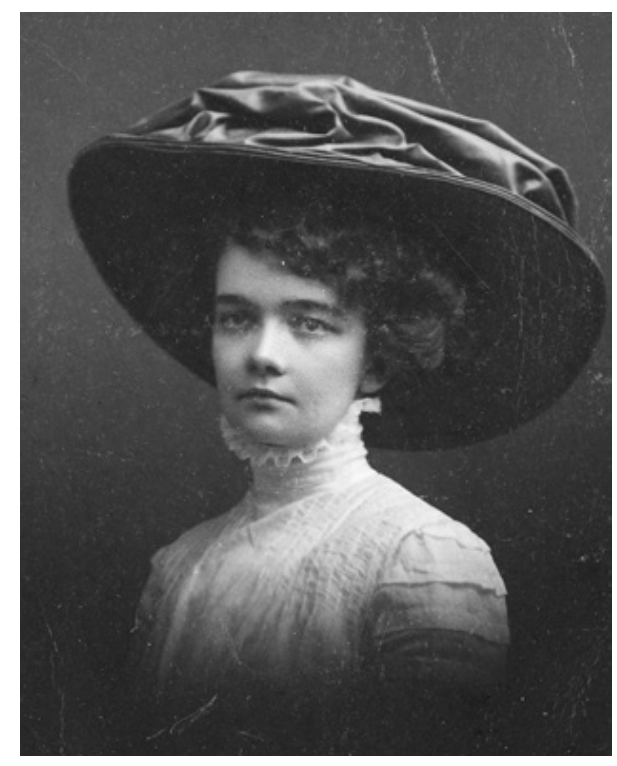

Tuleva kirjailija Kersti Bergroth elegantissa jugend-ajan hatussaan Viipurissa vuosina 1904-1905.

neja. ${ }^{108}$ Varhaisen draamatuotantonsa Bergroth sijoitti nykyaikaan. Sitä edusti Herra Vento (1921), ruots. Willy Wallén (1922), komedia nuoresta kirjailijasta, joka joutui kamppailemaan taiteellisten ideaalien ja toimeentulon, käytännössä keveämmän kirjoittamisen välillä. Suomenkielisenä komedia kiersi kahdeksassa teatterissa, mutta sitä esitettiin myös ruotsiksi. Vastaavia joskin vähemmän menestyneitä olivat komediat Oikea morsian (1925), kouluaiheinen komedia Maa huojuu (1927) ja Kannaksen lumous (1928) sekä myöhempi Prinssi tornissa (1952). ${ }^{109}$

Bergrothilta syntyi taajaan romaaneja ja mietelmäproosaa. ${ }^{110}$ Hän toimi Suomen antroposofisessa liikkeessä, jonka juuret olivat saksalaisessa kulttuurissa. Tämä heijastui hänen mietelmäkirjoissaan, myöhemmissä aforismeissaan ja runoissaan.

Pakinoitsijana "Tet" ja "Asser" -nimimerkkien takaa Bergroth toimi 1930-luvun ajan julkaisten edelleen romaaneja ja muuta proosaa." Bergrothin menestynein näytelmä Anuja Mikko esitettiin Helsingin kantaesityksensä jälkeen Viipurissa vielä samana vuonna (1932). Se kertoo pienyrittäjän vaikeuksista ja elämänuskosta. Yksi näytelmän klassisista komediahahmoista on Amerikan Mar', puhelias paluumuuttaja New Yorkista. Kannaksen murre, joka idyllisessä aikalaiskomediassa kukki, loi yhteisyyden tunnetta jo Viipurissa näyteltynä, mutta luonnollisesti entistäkin vahvemmin sotien jälkeen. Näytelmä filmattiin kahdesti (1940, 1956). Vastaavanlaisen nostalgian varaan rakentui komedia Kuparsaare Antti (1956), jossa niin ikään kuljetettiin rakkausaihetta yli luokkaerojen ajattomalla Kannaksen maaseudulla.

Bergrothin isänmaallis-kotiseudulliseen suuntaukseen liittyi Leon Grandellin (1894-1967) kanssa kirjoitettu Jääkärit (1933), joka vain 15 vuotta sisällissodan jälkeen esitettynä ei saanut pelkästään myönteistä vastakaikua. ${ }^{112}$ Nuoren lotan päiväkirja (1940) taas kantoi talvisodan henkeä. Kersti Bergroth käsikirjoitti sarjan sotavuosien viihteellisiä elokuvia, joissa hän pääsi jatkamaan nokkelaa dialogiaan ja luomaan modernia naiskuvaa. Valentin Vaalan ohjauksista ja Lea Joutsenon päärooleista on syytä muistaa Morsian yllättää (1941), Tositarkoituksella (1943), Dynamiittityttö (1944), Vuokrasulhanen (1945) ja Viikon tyttö (1946). ${ }^{13}$ Kaiken aikaa jatkui myös romaani- ja proosatuotanto. ${ }^{114}$

Runoihin modernistien sukupolven kriitikot suhtautuivat jo varauksellisesti. Siksi Bergrothin tuotannon painopiste siirtyi mietelmäkirjallisuuteen, vaikka rinnalla syntyi monia muistelmaepisodeja Viipurista sekä kulttuurikirjoja 
hänen toisesta asuinpaikastaan Roomasta. ${ }^{115}$ Sotien jälkeen Kersti Bergroth, Lempi Jääskeläinen ja Viljo Kojo julkaisivat Viipuria käsittelevän yhteisteoksen Rakas kaupunki (1951). Bergrothin kuolema Helsingissä 1975 omana 89-vuotispäivänään päätti tärkeän aikakauden Viipurin kirjallisessa perinnössä. Bergrothin tekstejä ilmestyi tosin vielä postuumisti teoksessa Oi aika Viipurin (1981).

\section{MUISTELIJOIDEN VIIPURI}

Viipurin ruotsinkielisten piirissä syntyi laji, josta 1900-luvulla muodostui Viipuria koskevan kirjallisuuden tunnusmerkki: lapsuusmuistelmat Viipurista. Lajityyppi syntyi jo silloin, kun Viipuri vielä kuului autonomiseen ja itsenäiseen Suomeen, mutta sai luonnollisesti vahvemmat värit, kun kaupunki oli menetetty. ${ }^{116}$

Varhaisimpia muistelijoita oli Åbo Akademin professori Alma Söderhjelm (1870-1949), joka teki uran Ranskan historian tutkijana ja Suomen ensimmäisenä naispuolisena historian professorina. Söderhjelmin muistelmateoksissa Min värld I-III (1920-1921) lapsuus- ja kouluvuosien Viipurilla ja sen seurapiireillä oli keskeinen osa. Söderhjelmin tavoin 1880-1890-luvun vuosista kirjoittivat Esther Höckert (1868-1947) ja Ingrid Borenius (1879-1948) teoksessaan Människor och minnen från Wiborg vid sekelskiftet (1940). Teos kertoo kronikoivaan tyyliin muutamien perhekuntien jäsenistä ja harrastuksista, etenkin musisoinnista. Myös kirjakauppias, liikemies ja konsuli Victor Hoving (1877-1970) julkaisi sotien jälkeen muistelmansa En wiborgare berätter för sina vänner (1944) ja En wiborgare i Helsingfors och Stockholm (1945), joista suomennettiin yhteisnide 1946. Hoving kirjoitti useita yrityshistorioita ja pakinakokoelman I gamla Viborg, taltes fyra språk (1960).

Muistelmia jykevämpi Viipurin elämänmuodon dokumentointi on Örnulf Tigerstedtin huolellinen historiateos Huset Hackman, I (1940) ja II (1952), jonka suomennokset nimellä Kauppahuone Hackman ilmestyivät jo samoina vuosina.

Muistelmakirjallisuus alkoi hallita 1930-luvulta lähtien suomenkielistäkin Viipuri-kirjallisuutta. Vuosisadan alun Viipurissa teatterinjohtajana toiminut Erkki Kivijärvi (1882-1942) laati kaupungin jätettyään muistelmansa Aurinko paistaa niin hyvien kuin pahojenkin päälle (1932). Hän kirjoitti myös Juho Lallukkaa käsittelevän romaanin Kauppaneuvos (1937). Niin ikään Jalmari Finnen muistelmiin Ihmeellinen seikkailu (posth. 1938) sisältyy Viipuri-jakso. Viipuria muistelivat teksteissään monet muutkin siellä työskennelleet.

Värikkäimpiä sotien jälkeen ilmestyneitä 1920-1930-luvun kuvauksia oli Jaakko Lepon (e. Ahlgren, 1902-1951) Viipurilaisia (1946) Lepon työvuosia ja kontakteja eläväsanaisesti käsittelevä teos valottaa niin Viipurin lehtimieselämää kuin Kaupunginteatterin asioita, joita kirjoittaja johtokunnan jäsenenä joutui hoitelemaan. 
Elettiin vielä sotienjälkeistä poliittisesti arkaa aikaa, kun Annikki Arnin (s. Forsström, 1898-1981) kirja Muistat sie viel? (1953) ilmestyi, tuolloin nimimerkillä Marja-Leena. Arnin isä Emil Forsström (1866-1927)oli yksi niistä hovioikeudenneuvoksista, jotka joutuivat 1910-luvun venäläistämisvuosina Krestyn vankilaan. Toiseen painokseen (1979) voitiin jo lisätä ensipainosta arkaluontoisempaa kerrontaa venäläisten toiminnasta. Kuvaus perheen vierailusta venäläisessä vankilassa ainakin on tarkka ja lahjomaton.

Vasta 1980-luku ja erityisesti Mihail Gorbatšovin aika Neuvostoliiton johdossa avasivat uuden vuon Viipuri-muistelijoille. Yksi varhaisista oli Katri Veltheimin (1918-2011) vuonna 1985 ilmestynyt Kultainen rinkeli, jossa koulutytön muistelmat 1930-luvun Viipurista oli rikastettu yleiseksi kulttuurihistoriaksi. Veltheim oli jo aiemmin (1958) tarkastellut Viipurin muistelmakirjailijoita, mutta havainnut, että kirjat olivat pääsääntöisesti tavanomaisia perhe- ja sukuhistorioita tai nuoruus- tai lapsuuskuvauksia. Itse kaupunkia, sen henkeä tai tunnelmaa ei vielä tuolloin ollut juurikaan kuvattu.

\section{HISTORIALLISTEN ROMAANIEN KAUPUNKI}

Jo 1890-luvulla julkaistu G. W. Laguksen Viipurin historiateos, jota J. W. Ruuth täydensi 1910-luvun alussa, ja näiden suomennokset ruokkivat mielikuvitusta ja lisäsivät tietoisuutta kaupungin historiasta ja sen monista vaiheista. Kaupungin historia tarjosi Viipurissa syntyneille tai kasvaneille kirjailijoille kiehtovan aihepiirin. Historiallisia romaaneja ja kertomuksia olivat kirjoittaneet jo Pietari Hannikainen, Johannes Alfthan ja Jac. Ahrenberg.

Itsenäisyyden ajan viipurilaisessa yhteisössä oli omat jännitteensä. Niistä osa oli kieliryhmien välisiä, mutta myös poliittisissa asetelmissa oli kipupisteensä. Valkoisille oli käsittämätöntä, että ennen niin itsenäisyysmielinen Viipurin työväki lokakuun vallankumouksen 1917 jälkeen äkkiä liittoutui venäläisten kanssa. Se oli mysteeri kenties työväelle itselleenkin. Sisällissodan tapahtumien käsittelyä ei helpottanut sekään, että Viipurin venäläisiin - niin punaisiin, puolueettomiin kuin valkoisiinkin - huhtikuun lopussa 1918 kohdistuneen suuren joukkosurman taustoja ei koskaan selvitetty kunnolla. Verilöylyn toteuttivat muualta tulleet valkoiset joukot. ${ }^{17}$

Sisällissodan haavat eivät parantuneet nopeasti. Viipurin kaupunkialueella asuttiin ahtaasti eikä moderni kaupunkirakentaminen päässyt esikaupungeissa vielä alkamaan. Suuren teollisuuskaupungin työväenjärjestöjen johdossa oli 1920-1930-luvuilla paljon sympatioita kommunisteja ja vasemmistososiaalidemokraatteja kohtaan. Vaaleissa työväki tosin äänesti yhä enemmän Tannerin johtamia sosiaalidemokraatteja. ${ }^{118}$ 


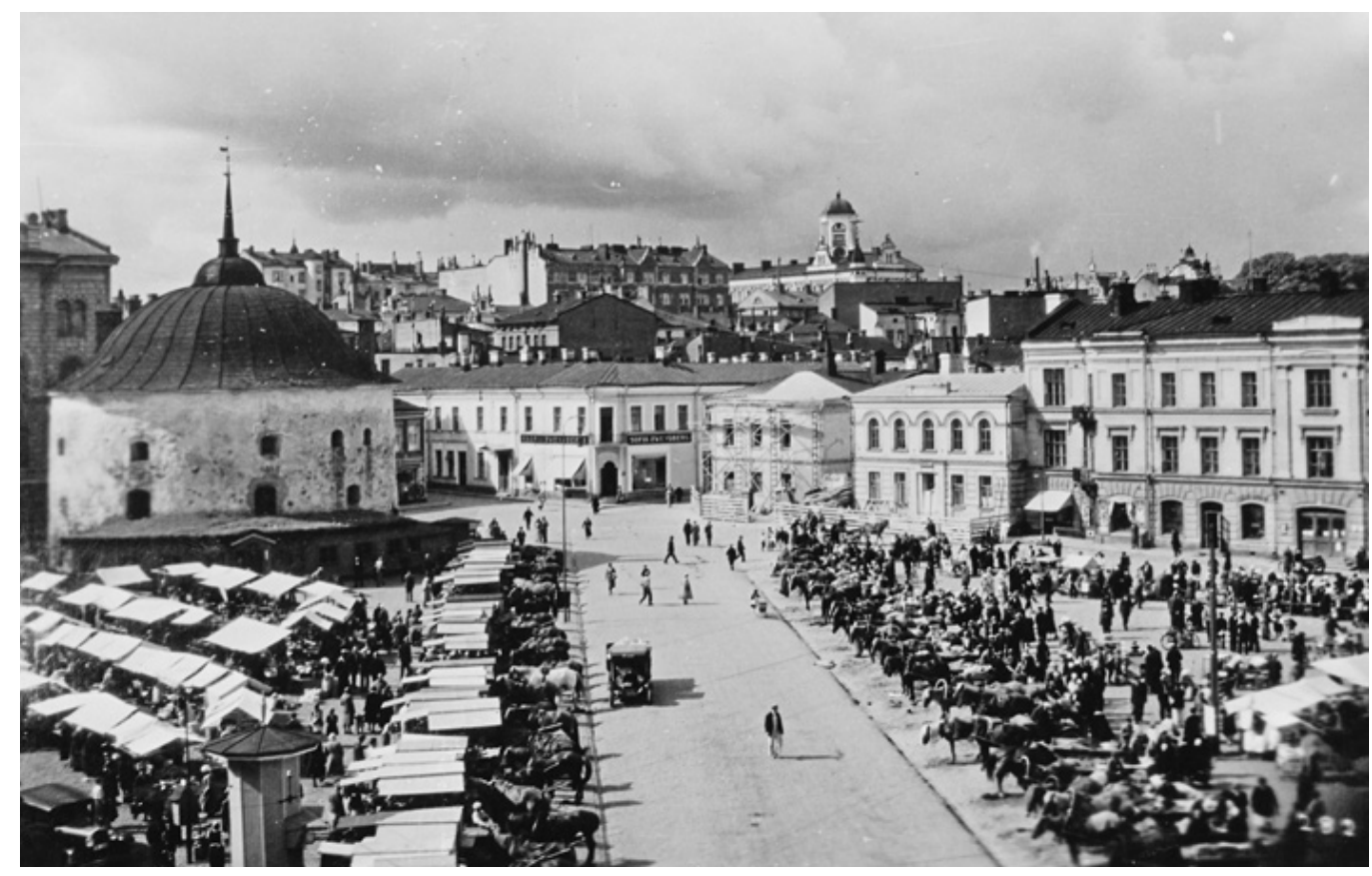

Viipurin kauppatori ja ravintolaksi muutettu pyöreä torni 1930-luvulla.

Viipurilaiset olivat varsin perillä historiastaan; asukkaat tiedostivat, että heidän kotikaupunkinsa suuri arvo oli sen iässä ja perinnön rikkaudessa. Vielä 1890-luvulla oli suunniteltu jopa pyöreän tornin purkamista, mutta torni päädyttiin kunnostamaan (1923). Sotiin asti siinä toimi ravintola. Vuonna 1933 perustettiin Torkkelin kilta vaalimaan kaupungin historiallista perintöä.

Historiallisten romaanien sarjansa aloitti tällaisissa tunnelmissa Lempi Jääskeläinen (1900-1964), jonka tuotannon kiinteys ja levinneisyys nostaa hänet muiden viipurilaisten kirjailijoiden yläpuolelle. Arkeologiaa opiskellut Jääskeläinen päätyi ensin verovirkailijaksi ja lopulta päätoimiseksi kirjailijaksi, joka sai valtionpalkinnon jo vuonna 1935. Hän julkaisi pitkälti yli 30 Viipurin historiasta ammentanutta romaania, joiden aikajänne ulottui keskiajalta 180o-luvulle. Tärkeimmät kokonaisuudet olivat Weckroothin perhe (1930, jatko-osat 1931, 1932, 1933; tiivistetty laitos 1944) sekä kolme romaania Natalia von Engelhartin vaiheista $(1935,1936,1937)$, mitkä hän sittemmin tiivisti yhteen romaaniin Helena Weckroothin tytär (1947).

Toinen maailmansota muodosti Jääskeläisellekin vedenjakajan. 1940-luvun alussa syntyivät muistelma- ja historiateokset Se oli Viipuri vihanta (1940), Vanhan Viipurin hiljaiseloa (1940), Viipuri ennen ja nyt (1941). Vasta tämän jälkeen jatkuivat romaanit: Kultainen laakeri (1954), Vanha Markovilla (1955) Hovin vallat (1956) Kevät vanhassa kaupungissa (1957) ja Nuori herra David [Alopaeus] Viipuris- 
ta (1963). Jääskeläisen tuotanto kului evakkosukupolven käsissä, mutta aivan valtakunnallista kirjallista arvostusta ne eivät ole saavuttaneet. ${ }^{19}$

\section{LOPUKSI}

Viipurin kirjallisuutta koskeva katsaus alkoi kahdesta suomenkielisestä uranuurtajasta, Juteinista ja Hannikaisesta. Heidän esimerkkinsä loi pohjaa sellaiselle dynaamiselle ajattelulle, jota 1850-1860-lukujen nuoret viipurilaiset sanankäyttäjät alkoivat levittää koko suuriruhtinaskuntaan. Kun suomen kielen asema vahvistui ja kieliryhmän osuus voimakkaasti kasvoi, alkoivat Viipurissakin monet ruotsinkieliset pelätä kulttuurisen asemansa heikkenemistä. Tällaisena ruotsalaisuuden merkityksen korostamisena näyttäytyvät Laguksen ja Ahrenbergin elämäntyöt Viipurin historiaharrastuksen lisäämiseksi ja ruotsalaiskeskeisen tulkinnan rakentamiseksi. ${ }^{20}$ Sittemmin kaupungin ruotsinkielisten vilkkaan seuraelämän muistelijat kuvasivat ymmärrettävästi omaa katoavaa elämänmuotoaan, kun kaupungin suomalaistumisesta ei enää ollut paluuta entiseen.

Viipurin kielisuhteista kiisteltiin ankarasti niin 1800-luvun lopulla kuin 1900-luvun alussakin. Toisaalta kielikysymys haastoi suomenkielisiä tunnistamaan omat suomalaisen muistin paikkansa. Niiksi tarjoutuivat myyttiseksi nostettu Mikael Agricola, jonka patsashankkeen rahoittamiseen valjastettiin laajasti kansalaistoimintaa. Muistin paikkoja tarjosivat myös Kalevala ja Karjala-kuvasto, samoin kuin viipurilainen kaunokirjallisuus. Lempi Jääskeläinen sijoitti historiallisten romaaniensa henkilöt aikaan, jolloin ruotsinkielinen säätyläistö ei vielä hallinnut kaupunkikulttuuria. Sopivatko saksalaissukujen vaiheet ja niiden suhde 170o-luvun suomalaisuuteen sellaiseksi Viipuri-teemaksi, joka rakensi itsenäiselle Suomelle kaivattua, mutta ruotsalaisuudesta riippumatonta historiaa?

Kiinnostava on niin ikään Kersti Bergrothin uran kaari. Hän aloitti jo kielivalintansa perusteella yksilöllisenä modernistina: kirjailija pitäytyi ensimmäiset vuotensa ruotsin kielessä ja kuvasi aikansa säätyläisnuoria elitistisestä näkökulmastaan. Muuttuvat aatteet ja poliittinen ilmapiiri muokkasivat hänestä myöhemmin kansallis- ja paikalliskirjailijan sovinnaisin maustein: populaarin elokuvakäsikirjoittajan, pakinoitsijan ja aforistikon.

Sukupolvien katsotaan määrittyvän jotakin ikäryhmää tai sen segmenttiä yhdistävänä, voimakkaana kokemuksena. ${ }^{21}$ Viipurin kirjallisessa historiassa erottuu ainakin kaksi vahvaa sukupolvikokemusta. Varhaisempi niistä oli 180o-luvun puolivälin rajoittava poliittinen ilmapiiri, joka teki Johannes Alfthanista ja C. I. Qvististä vakaumuksellisia uuden ajan airuita. Vielä selvemmin 
tunnistettava sukupolvikokemus olivat toisen maailmansodan menetykset.

Näiden aikakausien välillä eli suuri joukko kirjailijoita, joiden tuotannosta olisi kiinnostavaa selvittää, millaisena Viipurin kaupunki tai vaikkapa sisällissodan vaiheet teksteissä näyttäytyvät. Kulttuurihistoriallista arvoa taas olisi tutkimuksella, joka tarkastelisi, kuinka ensimmäisen teollistumiskauden pitkä taloudellinen noususuhdanne ja itsenäisyyden alkuvuosikymmenten taloudellinen toimeliaisuus kasvattivat kaupungin vaurautta ja loivat edellytyksiä laajan lukevan yleisön muodostumiselle. Miten Viipurin nousun vuosikymmenet artikuloituivat kirjallisuuteen? - Kysymys odottaa tutkijaansa.

\section{VIIPURIIN ERI TAVOIN LIITTYVIÄ KIRJAILIJOITA, SYNTYMÄVUODEN MUKAAN ${ }^{122}$ :}

Hirn (s. Bergroth), Eva 1877-1948

Voipio (e. Åkerman), Aino 1883-1975

Voipio (e. Åkerman), Väinö 1884-1976

Åkerman-Tudeer, Maija 1886-1984

Bergroth, Kersti 1886-1975

Väänänen,Kalle 1888-1960

Kojo, Viljo 1891-1966

Vuoriniemi, J. G. 1891-1939

Wrede, Mary 1892-1985

Sihvo, Sam 1892-1927

Pelkonen, Väinö 1894-1974

Wrede, Brita 1894-1973

Pimiä, Ilmari 1897-1989

Tigerstedt, Örnulf 1900-1962

Tolvanen, Allan 1900-19??

Tiittanen, Irene 1900-1971

Rauta (e. Niukkanen), Viljo 1902-1944

Paavolainen, Olavi 1903-1964
Pulli, Eero A. 1904-1973

Tollet, Håkan 1904-1980

Konkka, Juhani 1904-1970

Pohjakallio, Karl Aksel 1904-1986

Rauanheimo (e. Järnefelt), Yrjö 1904-1949

Pulla, Armas J. 1904-1981

Seppänen, Unto 1904-1955

Konttinen, Aili 1906-1969

Parland, Henry 1908-1930

Stenius, Göran 1909-2000

Nuorvala, Kaarlo 1910-1967

Parland, Ralf 1914-1995

Kähäri, Iris 1914-1995

Veltheim, Katri 1918-2011

Manner, Eeva-Liisa 1921-1995

Meri, Veijo 1928-2015

Krohn, Aarni 1930-2012 


\section{Viitteet}

1 Teperi 1965.

2 Esim. Kaukiainen 2014a, 9-10.

3 Wolff tässä kokoelmassa, 50.

4 Wolff 2014, 354.; Mäkinen tässä kokoelmassa, 176-178.

5 Lassila 2003, 252.

6 Kivi lähetti VSKS:Ile kolme näytelmää, joista lautakunta kelpuutti painettavaksi Lean. Teperi 1959, 19, 20, 24, 36.

7 Lallukkaa käsittelevä taloushistoriallinen elämäkerta: Markkanen 1967.

8 Mäkinen tässä kokoelmassa, 175-193.

9 Viimeksi lehdistöstä: Matikainen 2014a, 419-430; Stadius 2002; Matikainen tässä kokoelmassa, 162 alkaen.

10 Matikainen tässä kokoelmassa, 162-164.

11 Kirjapainojen historiasta Viipurissa: esim. Hirn 1973; Kuujo 1981, Kuujo 1981, 578-579.

12 Kaukiainen 2013; koko läänin osalta Hämynen 2014, 144-185.

13 Vuonna 1870 lähes puolet (42 \%) säätyläisistä oli ruotsinkielisiä; venäjän- tai saksankielisiä oli molempia noin neljännes.

14 Suomenmaan tilastollinen vuosikirja 1893. Taul. 4.; Turun kaupungin tilastollinen vuosikirja 2013, 32.

15 Thieme 2012 (1808); Teperi 1972, 95; Ruuth \& Kuujo 1981, 103-111; Riikonen 2012. Kaukiainen katsoo että Jacob Judénin ohella näiden koulumiesten oppilaat muodostivat 1820-luvulla Sanan Saattaja-lehden piirin. Kaukiainen 2014a, 33.

16 Esim. TalviOja 1915; Teperi 1972; Huhtala 2009; Hirn 1981, 105-106.

17 H. G. Porthanin nuoruuden työ De Poësi Fennica, Suomalaisesta runoudesta, (1750-1760-luvulla eri osina) katsottiin pitkään Suomen kulttuurihistorian merkittävimmäksi tieteelliseksi teokseksi.

18 "Wäinämöinen woimallinen, / Runon Isä riemullinen, / rakastettu, rauhallinen! / terwe tullen Wiipuriin, / Karjalinnan Kaupungiin! Sanan Saattaja Viipurista n:o 39: 29.9.1833; sekä Juteini 2009, II:90.

19 Juteini 2009 (1816), I:187-200.
20 Tekstit on julkaissut TalviOja 1915. Teperi 1972, 83. Kaukiainen toteaa, että papisto oli usein vilpittömästi talonpoikien asialla. Kaukiainen 2014a, 32.

21 Julius Krohn kuvaa Juteinin kirjailijalaatua sanomalla, että hänen "runottarensa on liikaa älyperäinen ja toisaalta lapsekas", silti hän on aina iloinen ja hilpeän reipas. Snellman luonnehtii 1850-luvulla Litteraturbladetissa Juteinia liian "tarkoitushakuiseksi” ollakseen suuri runoilija. Tarkiainen pitää Juteinia historiallisena ilmiönä, ei elävänä runoilijana. Tällaisen käsityksen luo myös Koskivirran historiografinen tarkastelu tässä kokoelmassa, 157, loppuviite 3.. Teperi taas asettaa Juteinin erityisesti poliittisten ja filosofisten ajatusten kanavaksi. J. Krohn 1897; Tarkiainen 1934; Teperi 1972.

22 Ensin Turun hovioikeus vapautti Judénin sakosta ja vuonna 1831 korkein oikeusaste eli senaatin oikeusosasto kumosi myös painoksen hävitystuomion. Huhtala 2009, 14; Heininen 2012b.

23 Teperi olettaa että Juteinin doctor honoris causa -arvo olisi tullut ansioista suomen kielen edistäjänä. Hän huomauttaa kuitenkin, että asiasta päättäneet professorit eivät ole osanneet lukea Juteinin suomenkielistä tuotantoa. Uskottavampaa on, että ruotsinkieliset kieli-, moraali- ja kasvatusfilosofiset teokset ovat tohtorinarvon perusteena. Kyyrö 1966, 17, 18, 44; Teperi 1972, 147-148.

24 Juteini 2009, II:200.

25 Kuuno TalviOjan Juteini-elämäkerta ilmestyi jo 1915. Laitinen omistaa Juteinille 11/2 sivua. K. Laitinen 1981, 167-169. Suunnilleen saman verran saavat runoilijat Kallio, Suonio ja Oksanen. Snellman ja Topelius saivat sivuja kaksin verroin enemmän, ja korkeimmalle arvostetut Runeberg ja Kivi 71\%2-8 sivua.

26 Esim. Koskivirta tässä kokoelmassa, 135-136

27 Kaukiainen 2014a, 30-34; Koskivirta 2014b 378-398; Koskivirta 2014c, 66-102. 
28 Koskivirta tässä kokoelmassa, 143-146

29 Kanawan toiminnasta: Kohtamäki 1959; Stadius 2002; Matikainen 2014a, 419-430.

30 Esim. Stadius 2002, 76.

31 Kohtamäki 1959; J. Krohn 1897.

32 Kohtamäki 1959, 22-24.

33 Kanawa 4.1.1845.

34 Kohtamäki 1959, 28.

35 Lagervallin neljä muuta näytelmää ovat nimeltään Judithi, Josephi, Kaini ja Tuhkapöperö. P. Paavolainen 2015, 30.

36 Kanawa 1845: 5, 6, 9, 11, 12. Esitystiedot: Silander, Alpo, "Pietari Hannikainen", Valvoja 12/1899, 738-753; Hirn 1970, 169, 228, 229; kootusti Pietilä 2003, 72-73. Erityisen mielenkiintoinen on Hannikaisen antama tieto: "Pari vuotta myöhemmin [1838 jälkeen] hän tarjosi näytelmänsä piskuisen Sanansaattajan toimittajalle, pastori Ignatiukselle lehteen painettavaksi. Mutta tämä ei ottanut sitä vastaan, selittäen sen sekä aiheeltaan että esitystavaltaan epäsopivaksi." Silander, Alpo, "Käynti suomalaisuuden ja sanomistomme kunniavanhuksen luona" (Kesäkuun 15 ja 16 p:nä 1899). Wiipuri 30.9.1899; myös Kohtamäki 1959, 50-54.

37 Hirn 1981, 504-505; Paavolainen tässä kokoelmassa, 68.

38 Kanawa 1845: 23-27, 32; Pietilä 2003, 74-75.

39 Kanawa 1846: 4, 5, 7, 8, 9, 10, 11. Joululahjukset ilmestyivät Kanawassa 1846: 49, 50, 1847: 1, 2, joissa Judén oli jo sensorina.

40 Vastaanottoa referoi Kohtamäki 1959, 51-54.

41 Kanawa 1846, 4, 5-11.

42 Kanawa 1846, 4. (28.1.1846).

43 Teema oli ajankohtainen sillä Fredrik Berndtsonin (1844) ironinen pienoiskomedia Fennomanen on voinut kirvoittaa Hannikaiselta oman versionsa samasta kansansivistyksen ja säätyläispoikien ja kansantyttöjen avioliitoista. Kanawa 1845, 23-27, 32; Pietilä 2003, 74-75.

44 Pietilä 2003, 74-77.
45 Bergbom ei mainitse erityisesti Hannikaista. Puheosaston näytelmistä Silmänkääntäjää toki alkuvuosina 1872-1879 kiertueella esitettiin ja se uusittiin 1893, jolloin Hannikainen täytti 80 vuotta. Oskari Wilhokaan ei halunnut varhaisvuosien ohjelmistoon näköjään muita Hannikaisen tekstejä. Myös Pietilä pohtii esittämättömyyden syitä: Pietilä 2003, 68-71.

46 Kanawa 1846, 43. (11.11.1846); Paavolainen tässä kokoelmassa, 70.

47 Kohtamäki 1959, passim. Kirjastoasioista: Mäkinen tässä kokoelmassa, §; Kouluasioista: Matikainen tässä kokoelmassa, 169.

48 Kohtamäki 1959, passim.

49 Maanviljelysseurat oli aluksi tarkoitettu säätyläismaanomistajille, vasta Aleksanteri II:n liberalismin kaudella avautuivat talonpojillekin.

50 "Ny proletärfabrik", Saima 1846, 10; alun perin "Uusi köyhälistö", Kanawa 1846, 7. Maaseudun rahvasta ajoi keväällä 1846 maantielle myös edellisenä syksynä koettu kato. Kohtamäki 1959, 139-140.

51 Kohtamäki 1959, 138, 139.

52 Casimir von Kothen oli upseeri, keisarin ja imperiumin puolustaja. Hän oli kenraalikuvernööri Menschikoffin suosikki, Lars Gabriel von Haartmanin lanko ja näin sukua myös Carl Gustaf Mannerheimille. R. Savolainen 2000.

53 Kohtamäki 1959, 138-142, 197-198.

54 Kohtamäen mukaan von Kothen sai poikkeavat sensuurivaltuudet läänissään 11.5.1846 annetussa käskykirjeessä. Jo huhtikuussa 1846 von Kothen oli kieltänyt julkaisemasta kirjoitusta ennen kuin se oli käännetty. Kanavassa 27.5.1846 jutun tilalle painettiin A. Poppiuksen runo ilman, että tältä oli kysytty asiaa. Kanawa 1846, 20; Kohtamäki 1959, 198-199, 212-213.

55 Kohtamäki 1959, 204-205.

56 Tällaisia tapauksia Kohtamäki kuvaa kolme, mutta olettaa että kaikki sensuuritoimet eivät näy lehden lukijalle. Kohtamäki 1959, 204-205. 
57 Kohtamäki 1959, 204, 211. Kuvaus on näin tavallaan sortovuosiretoriikan sävyttämää. Teperi ei edes mainitse Juteinin toimintaa sensorina: Teperi 1972. Ei myöskään Tarkiainen 1934; eikä K. Laitinen 1981. Ensimmäisen kerran Kanavan imprimaturin antaja oli Jac. Judén 10.6.1846, siihen asti vielä Thesleff, joka kuoli 7.6.1846. Hirn ei näe Juteinin toiminnassa (kirjailijanakaan) mitään myönteistä, ja tuomitsee tämän suostumisen sensoriksi. Hirn 1981, 503504. Hirn muistuttaa vielä, että Judénilla oli suunnitelmissa kilpailevan kirjapainoluvan saaminen, mikä oli nähtävästi kuvernöörin tuella suunnattu Cederwallereita vastaan. Tarkemmin: Hirn 1973.

58 Tieto von Kothenin kirjeestä A. A. Thesleffille: Kohtamäki 1959, 209.

59 Judén oli hankkinut privilegion toista, kilpailevaa kirjapainoa varten ja Cederwallerilla oli uhka menettää kuvernöörin kanslian painotilaukset, mikäli tämä ei kuuntelisi kuvernöörin varoituksia. Kohtamäki 1959, 199-201, 209-210.

$60 H$ [annikainen, Pietari], "Sensuri-sääntö vuodelta 1851", Uusi Suometar 20.2.1885

61 Kohtamäki esittää lainauksen Cederwallerin kirjeestä Lönnrotille 9.12.1847: "Osittain vähäisen tilaajamäärän takia, osittain sen vuoksi, että ei ole mahdollisuuksia saada mitään kelvollista kirjoitusta hyväksytyksi [- - ] kaikki pyyhitään, kaiken yli vedetään risti. Kothen ja Sensori - valitettavasti kyllä suomalainen Judén, joka nyt näyttää olevan Kothenin kaikkein nöyrin palvelija [- - ] ovat miltei raivoja." [Poistot Kohtamäen]. Kohtamäki 1959, 208.

62 Kohtamäki 1959, 212-213. TalviOja viittaa D. E. D. Europaeuksen kirjeeseen, jonka mukaan Hannikaisen aikoessa perustaa Sanan Saattajan uudelleen tammikuussa 1849 von Kothen olisi sanonut, että kirjoitettiinpa siinä mitä vain, se ei saisi ilmestyä. TalviOja 1915.

63 Robert von Trappin Den unge juristen -teoksen käännösmukaelma. Koskivirta 2014c, 76.
64 Kohtamäki kuvaa Hannikaisen toimintaa näiden myöhempien lehtien piirissä. Kohtamäki 1959, 213-314.

65 Krohn ei mainitse Juteinin toiminnasta sensorina. Krohn, Julius. "Jaakko Juteini". Valvoja 11/1891, 5.-6; J. Krohn 1897.

66 Muistokirjoitus Uusi Suometar 29.9.1899; Silander, Alpo, "Käynti suomalaisuuden ja sanomistomme kunniavanhuksen luona" (Kesäkuun 15 ja 16 p:nä 1899). Wiipuri 30.9.1899; Silander, Alpo, "Pietari Hannikainen". Valvoja 12/1899, 738-753. Laitinen pitää Silmänkääntäjää ensimmäisenä esittämiskelpoisena näytelmänä, mutta ei esittele hänen muuta näytelmätuotantoaan. K. Laitinen 1981, 205-206.

67 P. Paavolainen 2014, 73-74.

68 Osakuntaelämästä: Matikainen 2014b, 342-343. Alfthanin taustasta: esim. Teperi 1967, 61.

69 Hirn 1981, 506-507; Teperi 1967, 17 viite.

70 Hegelistä väitöskirjan tehnyttä C. I. Qvistiä on luonnehdittu liberaaleista radikaaleimmaksi ja leppymättömimmäksi. Menetettyään koleraepidemiassa perheensä Qvist luopui toimittajan urasta ja opiskeli lääkäriksi. Uuden uran hän teki Helsingin kaupunginlääkärinä. Stadius 2002, 84-88; Railo 2001; Matikainen 2014a.

71 Veljekset Henrik Konstantin ja Axel Gabriel Corander toimittivat samaan aikaan lehteä Sanan-Lennätin (1856-1858), joka jatkoi sosiaalista suomalaisuuslinjaa. Mukaan tuli vielä Pietari Hannikainen. Lehti yhdistettiin Hannikaisen aikakauskirjaan Aamurusko - sanaisia lapsille, joka sekin lakkasi vuoden 1859 lopussa. Teperi 1967, 16-17.

72 Stadius 2002, 83; Einonen 2013.

73 Stadius 2002, 85

74 Stadius 2002, 84-85; Matikainen 2014a.

75 Wiborg 1.4.1856, pääkirjoitus.

76 Stadius 2002, 84-85, 87.

77 Yrjö Koskinen pelkäsi liberaalien löytävän toisensa yli kielirajojen, mikä olisi sekoittanut snellmanilaisen ohjelman. Rommi \& Polhs 1989, 75-83; Stadius 2002, 87.

78 Esim. Kuujo 1981, 578. 
79 Mallenius, Robert. "Muistelmia suomalaisuuden harrastuksista ja riennoista takavuosilta Viipurissa." Kirjoitussarjan ensimmäiset neljä osaa: Viipuri 3.8.1894/177, 8.8.1894/181, 16.8.1894/188, 22.8.1894/193.

80 Hirn 1960; Hirn 1981, 508.

81 Kyyrö ilmaisee kohteliaasti kiertäen, että Polén oli kirjoittanut suurimman osan teoksesta Kirjallinen aarreaitta, joka sekin oli "raskas seuran taloudelle." Kyyrö 1966, 133.

82 J. Krohn 1897, pieni autobiografia; Lassila 2003.

83 "Juliaanit ja leopoldiaanit" ovat VSKS:n edesmenneen esimiehen Aarni Krohnin keskustelussa käyttämiä nimityksiä.

84 Grotenfelt 1889; J. Krohn 1897. Jaakko Juteinin vaikutuksesta näihin ei-akateemisiin kirjoittajiin: Kuismin 2012.

85 Krohn kuvaa: "Vanhin mainituista runoilijoista ja osaksi edelliseen ajanlohkoon luettava on Konstantin Schröder. Hän oli syntynyt 29 p. Kesäk. 1808 Uukuniemellä, jossa isä oli kirkkoherrana. Tuli ylioppilaaksi 1826, vihittiin papiksi 1834 ja nimitettiin v. 1837 kirkkoherraksi Valkeasaareen Inkerinmaalle, jossa virassa kuoli 9 p. Elok. 1868. Myös oli hän Suomen Julkisten Sanomain ensimmäinen toimittaja vv. 1857-58. Schröderin runoelmia ja suorasanaisia kirjaelmia, joista osa on kirjoitettu salanimellä Lieto, löytyy jo Sanansaattajasta ja Mehiläisestä, sittemmin Maamiehen Ystävästä, Kanavasta ja Suomettaresta. Hänen tunnelmarunoistaan mainittakoon esim. 'Vait!'” J. Krohn 1897.

86 J. Krohn 1897, viite 194.

87 Grotenfelt 1889, passim.

88 Grotenfelt 1889; J. Krohn 1897.

89 J. Krohn 1897.

90 Novellin kirjoitusajankohta on epäselvä, se on todennäköisesti laadittu jo Puolan kapinan vuosina, vaikka julkaistiin vasta myöhemmin. P. Paavolainen 2014, 189.

91 Genetzistä: esim. Vares 2001; Erkosta: esim. Kulha 2000.

92 Markkanen 1967, 114-118.
93 Mesenoinnin käsitteellä voidaan tarkoittaa paitsi jonkin yleisöryhmän tapaa kannattaa johdonmukaisesti omaksi koettua taiteilijaa tai pelkästään jonkun tarjoamia työskentelyolosuhteita kirjailijalle. Jälkimmäisestä tunnetuin esimerkki on Charlotta Lönnqvistin 1860-luvulla antama suoja Aleksis Kivelle.

94 Ripatti 2011.

95 Ahrenbergin teoksia on runsaasti, joista mainittakoon: Hemma, Skildringar från Östra Finland 1887, Hihuliter Skildringar från Östra Finland 1889, Österut Berättelser 1890, Anor och Ungdom, Två berättelser 1891, Stockjunkarn, En berättelse från Karelen 1892, Familjen på Haapakoski 1893, Från Karelen Vald samling berättelser och kulturbilder 1894, Med styrkans rätt, Äfventyr och strider i österled 1899.

96 Alhoniemi 1972, 133-139. Ahrenbergin monikielisyyttä on tutkinut Julia Tidigs, jolla on myös katsaus Ahrenberg-tutkimukseen: Tidigs 2014, 32-36.

97 E. Ekelund 1943, 370.

98 Kirjailijoiden ammatillisesta yhteenkuuluvuudesta voisi pitää esimerkkeinä Minna Canthin ystäviä ja suojatteja, ja esimerkiksi ns. Päivälehden piiriä. Sanomalehtityön ohella kirjailijat hankkivat elantoaan suomennostyöllä.

99 Näytelmä on ruotsinnettu nimellä En kämpe utan svärd (1901).

100 Järnefeltistä: esim. Niemi 2005.

101 N. R. af Ursin istui sukunsa päämiehenä säätyvaltiopäivien aatelissäädyn edustajana ja sittemmin yksikamarisen eduskunnan sosialistisena varapuhemiehenä.

102 KK: käsikirjoitukset, Ida Aalbergin arkisto, Coll 1.2, Emilie Bergbomin kirje Ida Aalbergille 21.7.1887.

103 A. Kostiainen 2013; Hällström 1946.

104 Mäkelän näytelmää selostaa Päivälehti 19.11.1896.

105 Modernismiin ja avantgardeen liittyy yleisesti kosmopoliittisuus ja kansallisen kielipolitiikan rajojen ylitys. Suomenruotsalaisen kirjallisuuden kielinormeista: Tidigs 2014, 18-20. 
106 Laitinen 1967 ei mainitse Bergrothia lainkaan. Ruotsinkielinen kirjallisuudenhistoria käsittelee Bergrothin nuoruuden teoksia: Forssell 2000. Uusin suomenkielinen kirjallisuudenhistoria esittelee Bergrothin kaupunkilaisen modernismin ja naiskuvan kannalta sekä tyttö- ja viihdekirjan näkökulmasta: Rojola 1999.

107 Bergrothin kaksikielisyyttä on tutkinut Heidi Grönstrand. Grönstrand 2011. Bergrothin isä oli ollut suomalaisuusmies, joka kuitenkin asettui myöhemmin puolustuskannalle ruotsin kielen säilyttämiseksi. Kerstin ensimmäinen kielivalinta (ruotsi) herätti vanhasuomalaisten piirissä paheksuntaa. Forssell 2000, 57.

108 Esim. Evas klass 1917, Eevan luokka 1917, Litet mer om Eva 1918, Vähän enemmän Eevasta 1918, Yhteiskoululaisia 1921, Högsta klassen 1921, Första året 1923, Hyvästi, Eeva! 1923, Luokan ikävin tyttö 1925, Minnas hösttermin 1926, Minnan syyslukukausi 1926, Luokan merkkihenkilöitä 1938.

109 Koskimies 1972, 120, 193.

110 Kiirastuli 1922, Ensimmäinen taivas, 1923, Miellyttämisen taito: oppikirja "epäonnistuneille" 1925, Elisabeth 1925, Ilojen tie, 1926, Miten elät? 52 omaa sisintä ajatustasi (1926), Suurin hulluus auringon alla 1928, Jukka ja Laila, ikuisesti naisellista kaksinpuhelua 1929, Uusia sieluja 1930 ja Miten elät? 104 omaa sisintä ajatustasi 1931.

111 Kamrater emellan 1933, Toverien kesken 1933, Heräjä, armas synnyinmaa 1935; Suloisia aikaihmisiä, pakinoita 1936, Kuinka saisin elämäni hauskaksi 1938, Ett liv på jorden 1939, En ung lottas dagbok 1940, Nuoren lotan päiväkirja 1940.

112 Jääkärit-näytelmän kolmessa episodissa esitellään jääkäriliikkeen vaiheita. Aluksi kuvataan nuorten lähtijöiden piileskelyä etappitalossa santarmien jahtaamana, sitten elämää kasarmissa ja taistelemista Saksan itärintamalla Venäjää vastaan. Kolmannessa vaiheessa jääkärit palavat vapauttajina Etelä-Suomeen. - Teos ei koskaan saanut sellaista yleisön suosiota kuin Sam Sihvon Jääkärin morsian 1921.

113 Elonet. Suomen Kansallisfilmografia (www.elonet.fi, luettu 20.9.2015).

114 Oma muotokuva 1942, Hymyile kanssani, pakinavalikoima 1943, Eläviä ja kuolleita, romaani 1945, Minun äitini. Suomalaisia äitejä lastensa kuvaamina. 1946, Tämä elämä, 1948, Neljä viidesluokkalaista 1958, Anja, 1949, Sinä ja minä 1949, Kuninkaita 1949, Esseitä 1950, Katseita maailmaan 1950.

115 Teokset 1-5, 1952-1953, Sinä ja minä 1952, Prinssi tornissa 1953, [K Bergroth kahdentoista kirjoittajan kuvaamana 1954], Muistiinpanoja 1955, Salaisuutemme 1955, Oikea morsian 1955, Kirje taivaaseen, 1955, Rooman kävijöitä 1957, Maailman Rooma 1957, Tervetuloa Roomaan, opaskirja 1960, Rom - romare och romfarare 1960, Luokkakokous 1970, Alkusoitto 1971, Löytöretki 1973, Meidän elämämme täällä. aforismeja 1973.

116 Höckert \& Borenius 1940; Hällström 1946.

117 Keskisarja 2013, 311-323.

118 Soikkanen 1978.

119 Tieto on saatu huhtikuussa 2011 Viipurin oppaalta ja tulkilta Tatjana Shumilinalta, joka on järjestänyt mm. Jääskeläisen romaanien tapahtumapaikkojen mukaisia kaupunkikierroksia. K. Laitinen 1981 ei mainitse Lempi Jääskeläistä.

120 Knapas tässä kokoelmassa, 225-227.

121 Sukupolviteoriaa Suomessa käsitelleitä teoksia: Roos 1987; Purhonen, Hoikkala, \& Roos 2008.

122 Launonen 1981; Hirvonen 1993. 